bioRxiv preprint doi: https://doi.org/10.1101/2020.08.25.265926; this version posted August 25, 2020. The copyright holder for this preprint (which was not certified by peer review) is the author/funder, who has granted bioRxiv a license to display the preprint in perpetuity. It is made available under aCC-BY-NC-ND 4.0 International license.

\title{
MICROVASCULAR ENDOTHELIAL CELL ADAPTATION TO HYPOXIA IS ORGAN-SPECIFIC AND CONDITIONED BY ENVIRONMENTAL OXYGEN
}

Moritz Reiterer ${ }^{1,2}$, Amanda J Eakin ${ }^{1}$, Aileen Burke ${ }^{1}$, Randall S Johnson ${ }^{2,3}$ and Cristina M Branco ${ }^{1,4, *}$

\section{Graphical Abstract}

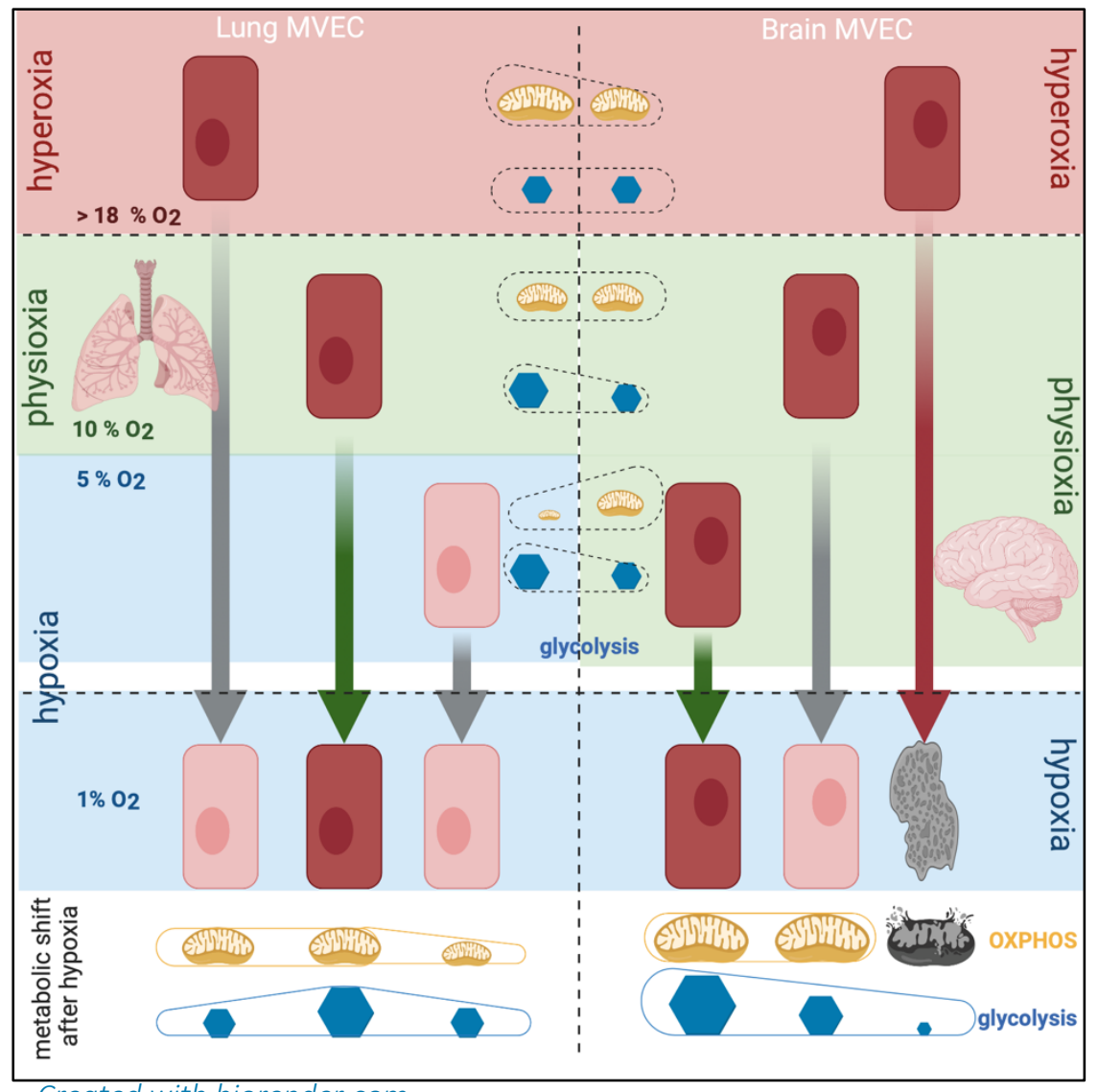

Created with biorender.com
In brief

Hypoxia sensing by microvascular endothelial cells (MVEC) is organspecific, and efficacy of response is affected by external oxygen. While glycolytic capacity is mostly maintained in MVEC regardless of organ or origin, mitochondrial function is required for adequate sensing and timely metabolic shift to glycolysis. Hyperoxygenation of MVEC compromises mitochondrial function, glycolytic shift and survival to hypoxia.

\section{Highlights}

- Environmental $\mathrm{O}_{2}$ influences MVEC hypoxia response in an organ-specific fashion

- Brain MVEC are unable to respond and survive to hypoxia if hyperoxygenated prior to stress

- MVEC glycolytic capacity is not affected by $\mathrm{O}_{2}$, but the increase in glucose uptake and shift to glycolytic metabolism stifled and delayed in hyperoxidized MVEC

- High $\mathrm{O}_{2}$ ablates activity of mitochondria complex II in brain MVEC, significantly disturbing succinate levels

Disruption of mitochondrial integrity compromises hypoxia sensing irrespective of glycolytic capacity

\footnotetext{
${ }^{1}$ Patrick G Johnston Centre for Cancer Research, Queen's University Belfast

${ }^{2}$ Department of Physiology, Development and Neuroscience, University of Cambridge

${ }^{3}$ Department of Cell and Molecular Biology, Karolinska Institute, Stockholm

${ }^{4}$ Lead contact

*Correspondence: C.Branco@qub.ac.uk
} 
bioRxiv preprint doi: https://doi.org/10.1101/2020.08.25.265926; this version posted August 25, 2020. The copyright holder for this preprint (which was not certified by peer review) is the author/funder, who has granted bioRxiv a license to display the preprint in perpetuity. It is made available under aCC-BY-NC-ND 4.0 International license.

Organ-specific and $\mathrm{O}_{2}$-dependent endothelial hypoxia responses

\section{SUMMARY}

Microvascular endothelial cells (MVEC) are plastic, versatile and highly responsive cells, with morphological and functional aspects that uniquely match the tissues they supply. The response of these cells to oxygen oscillations is an essential aspect of tissue homeostasis, and is finely tuned to maintain organ function during physiological and metabolic challenges. Primary MVEC from two continuous capillary networks with distinct organ microenvironments, those of the lung and brain, were pre-conditioned at normal atmospheric ( $21 \%$ ) and physiological (5 and $10 \%) \mathrm{O}_{2}$ levels, and subsequently used to compare organ-specific MVEC hypoxia response. Brain MVEC preferentially stabilise HIF-2 $\alpha$ in response to hypoxia, whereas lung MVEC primarily accumulate HIF-1 $\alpha$; however, this does not result in significant differences at the level of transcriptional activation of hypoxia-induced genes. Glycolytic activity is comparable between brain and lung endothelial cells, and is affected by oxygen pre-conditioning, while glucose uptake is not changed by oxygen pre-conditioning and is observed to be consistently higher in brain MVEC. Conversely, MVEC mitochondrial activity is organspecific; brain MVEC maintain a higher relative mitochondrial spare capacity at $5 \% \mathrm{O}_{2}$, but not following hyperoxic priming. If maintained at supra-physiological $\mathrm{O}_{2}$ levels, both MVEC fail to respond to hypoxia, and have severely compromised and delayed induction of the glycolytic shifts required for survival, an effect which is particularly pronounced in brain MVEC. Oxygen preconditioning also differentially shapes the composition of the mitochondrial electron transport chain (ETC) in the two MVEC populations. Lung MVEC primed at physioxia have lower levels of all ETC complexes compared to hyperoxia, an effect exacerbated by hypoxia. Conversely, brain MVEC expanded in physioxia display increased complex II (SDH) activity, which is further augmented during hypoxia. SDH activity in brain MVEC primed at $21 \% \mathrm{O}_{2}$ is ablated; upon hypoxia, this results in the accumulation of near-toxic levels of succinate in these cells. Our data suggests that, even though MVEC are primarily glycolytic, mitochondrial integrity in brain MVEC is essential for metabolic responses to hypoxia; these responses are compromised when cells are exposed to supra-physiological levels of oxygen. This work demonstrates that the study of MVEC in normal cell culture environments do not adequately represent physiological parameters found in situ, and show that the unique metabolism and function of organ-specific MVEC can be reprogrammed by external oxygen, significantly affecting the timing and degree of downstream responses.

\section{KEYWORDS}

Microvascular endothelial cell, hypoxia, hyperoxia, mitochondria, metabolic reprograming, organ-specific 
bioRxiv preprint doi: https://doi.org/10.1101/2020.08.25.265926; this version posted August 25, 2020. The copyright holder for this preprint (which was not certified by peer review) is the author/funder, who has granted bioRxiv a license to display the preprint in perpetuity. It is made available under aCC-BY-NC-ND 4.0 International license.

Organ-specific and $\mathrm{O}_{2}$-dependent endothelial hypoxia responses

\section{INTRODUCTION}

Microvascular endothelial cells (MVEC) are the most heterogeneous, versatile and specialised cells within the vascular tree (Augustin and Koh, 2017) (Aird, 2011), and are essential to organ function, which they regulate by locally adjusting nutrient, signalling and gas exchange rates to match organ demand to systemic availability (Reiterer and Branco, 2020). Angiocrine stimuli from resident MVEC mediate organ function and tissue microenvironment, which are also highly diverse in complex organisms (Zhang et al., 2020). Oxygen availability is dynamic and dependent on a tissue's cellular components and metabolic activity, and as such, perception and response to oxygen levels by MVEC is critical to organ homeostasis, and effectively sidesteps autonomic control (Nolan et al., 2013; Reiterer and Branco, 2020). This plasticity underlies functions beyond perfusion and permeability, and ensures organ performance in a variety of physiological contexts, such as exercise or high altitude (Prefaut et al., 2000; Rojas-Camayo et al., 2018) or pathological conditions (Brahimi-Horn et al., 2007; Eltzschig and Carmeliet, 2011; Kent et al., 2011; Mistry et al., 2018), as well as during tissue remodelling and regeneration(Ding et al., 2010; Ding et al., 2011; Ding et al., 2015). MVEC are functionally and metabolically equipped to respond to hypoxia, and organisms are for the most part capable of seamlessly adjusting to $\mathrm{O}_{2}$ flux at systemic and local levels. When stretched too far or for too long beyond the normal physiological range, these cellular responses can escalate to exacerbate pathologies involving vascular dysfunction (Reiterer and Branco, 2019). Examples include diabetic retinopathy (Cai and Boulton, 2002) and atherosclerosis (Gimbrone and García-Cardeña, 2016)..

MVEC can also be exposed to supra-physiological oxygen levels (hyperoxia), often by elective use of oxygen for therapeutic purposes. Intra- and post-operative hyperoxia is frequently employed to increase neutrophilmediated bactericidal activity, presumably by increased ROS production (Allegranzi et al., 2016; Hopf, 1997). Hyperbaric oxygen treatments are used for refractory diabetic wounds or to potentiate radiation efficacy (Chen et al., 2015; Goldman, 2009; Thom, 1989; Thom et al., 2011), as well as during diving (Banham, 2011). Unlike hypoxia, hyperoxia represents a non-physiological stimulus, which does not occur absent modern technology, and therefore, no evolutionary adaptation to it has taken place. Although clinically important, the effects of hyperoxia on MVEC function and plasticity have not been studied, with some exceptions on the effects on lung microvasculature (Ahmad et al., 2004; Kistler et al., 1967; Mach et al., 2011; Narula et al., 1998).

MVEC responses are presumed unique to the tissue they reside in, and in this study, MVEC from two continuous capillary networks from distinct microenvironments, lung and brain, were compared in their responses to hypoxia. We have found that environmental oxygen priming conditions the MVEC response to subsequent hypoxia. This conditioning affects both timing and amplitude of subsequent responses to hypoxia, and does so in an organ-specific fashion. 
bioRxiv preprint doi: https://doi.org/10.1101/2020.08.25.265926; this version posted August 25, 2020. The copyright holder for this preprint (which was not certified by peer review) is the author/funder, who has granted bioRxiv a license to display the preprint in perpetuity. It is made available under aCC-BY-NC-ND 4.0 International license.

Organ-specific and $\mathrm{O}_{2}$-dependent endothelial hypoxia responses

\section{RESULTS}

\section{Brain and lung microvascular endothelial cells respond differently to hypoxic stress}

Primary murine brain and lung microvascular endothelial cells (IMVEC) were cultured in standard atmospheric conditions and subsequently exposed to hypoxia $\left(1 \% \mathrm{O}_{2}\right)$ for up to $48 \mathrm{~h}$. Cell viability was shown to decrease in both MVEC over time (Figure 1A), but the effect occurred earlier and was visibly more pronounced in bMVEC. Similarly, a real-time viability assay (Duellman et al., 2015) (Figure 1B) showed a more severely decreasing bMVEC growth curve.

As known key mediators of hypoxia response, activation of the two main HIF- $\alpha$ isoforms (HIF-1 $\alpha$ and HIF-2 $\alpha$ ) was assessed in both MVEC populations, to investigate if discrepancies in the HIF-signalling pathway corresponded to differences in cell viability. HIF-1 $\alpha$ expression showed the canonical transient upregulation in both lung and brain MVEC (Bartoszewski et al., 2019; Reiterer et al., 2020; Uchida et al., 2004), although consistently higher levels of this isoform was found in cells from the lung, at all time points (Figure 1C). HIF$2 \alpha$ protein levels decreased only at later time points for IMVEC, but bMVEC showed strikingly higher levels of HIF-2 $\alpha$ protein throughout the hypoxia time course (Figure 1D).

Selected transcriptional HIF targets were quantified and, as expected, glycolytic genes PGK, LDH-A, and GLUT1 were upregulated in both MVEC, suggesting that HIF- $\alpha$ isoform preference does not necessarily underlie transcriptional activation of typical hypoxia induced genes; Even though the relative upregulation differed for each target, such as significantly more upregulated PGK transcript in IMVEC, or earlier upregulation of LDH-A in BMVEC, after $24 \mathrm{~h}$ of hypoxia the fold induction was no longer different between cell populations. One interesting distinction is that hypoxic IMVEC increasingly accumulated VEGF and ARG2 mRNA over time in hypoxia, but levels of either of those transcripts were seen to decrease in BMVEC, particularly unexpected for ARG2, considering this is considered primarily a HIF-2 $\alpha$ target (Krotova et al., 2010) (Figure 1C). BNIP3, a HIF$1 \alpha$ target(Bellot et al., 2009; Keith et al., 2011; Liu and Frazier, 2015), was upregulated more strongly in brain than IMVEC, which correlates with the higher susceptibility to hypoxia-induced cell death seen in cells isolated from the brain (Figures $1 \mathrm{~A}$ and $\mathrm{B}$ ), but not HIF isoform preference.

These data show that MVEC from brain and lung display markedly distinct responses to hypoxia, including survival and HIF isoform stabilization, but the differences in hypoxia-driven transcriptional activation was not as strikingly affected.

In vivo oxygen tension in brain tissue $\left(\sim 5 \% \mathrm{O}_{2}\right)$ (Dings et al., 1998) is much lower than that found in the lung ( $10 \%)\left(\right.$ Wild et al., 2005), implying that bMVEC would be better equipped to survive an exposure to $1 \% \mathrm{O}_{2}$. Paradoxically, bMVEC were more adversely affected by hypoxia, indicated by their reduced viability, and 
bioRxiv preprint doi: https://doi.org/10.1101/2020.08.25.265926; this version posted August 25,2020 . The copyright holder for this preprint (which was not certified by peer review) is the author/funder, who has granted bioRxiv a license to display the preprint in perpetuity. It is made available under aCC-BY-NC-ND 4.0 International license.

Organ-specific and $\mathrm{O}_{2}$-dependent endothelial hypoxia responses

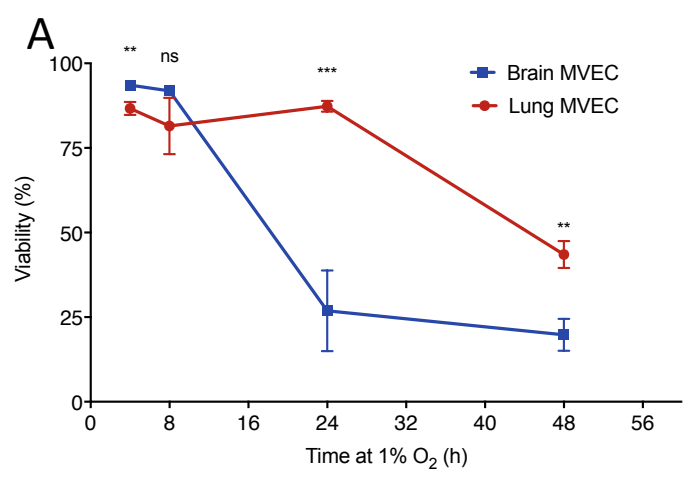

C

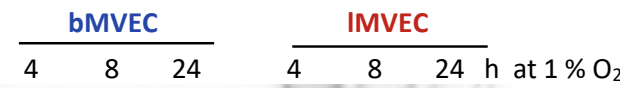

HIF-1 $\alpha$
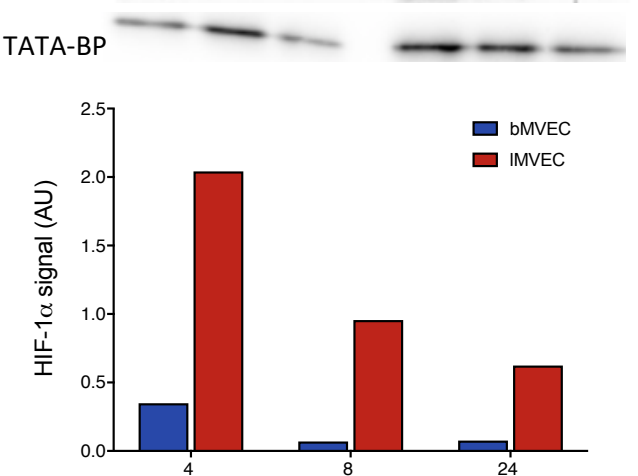

Time at $1 \% \mathrm{O}_{2}(\mathrm{~h})$

E
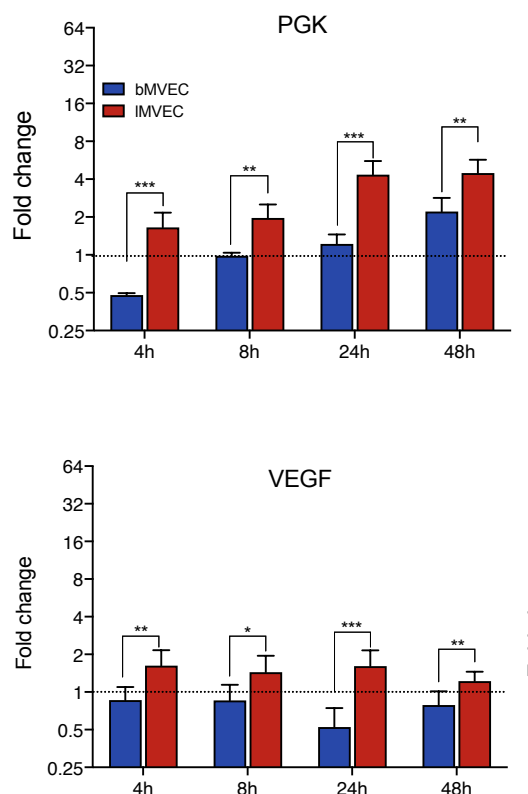

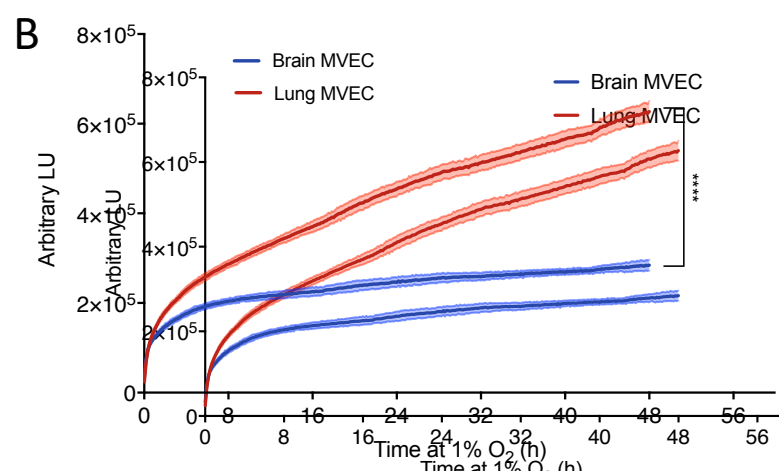

D

$$
\begin{aligned}
& \begin{array}{lcr}
\multicolumn{3}{c}{\text { bMVEC }} \\
\hline 4 \quad 8 \quad 24
\end{array} \\
& \frac{\text { IMVEC }}{4-24 h} \text { at } 1 \% \mathrm{O}_{2}
\end{aligned}
$$

HIF-2o

$\beta$-actin

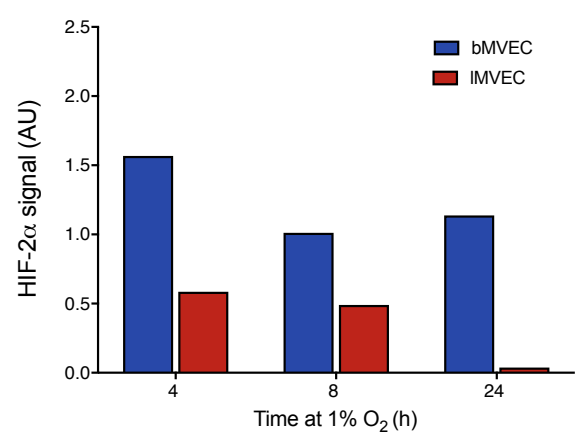

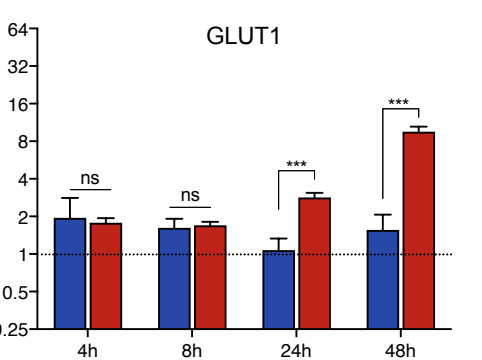
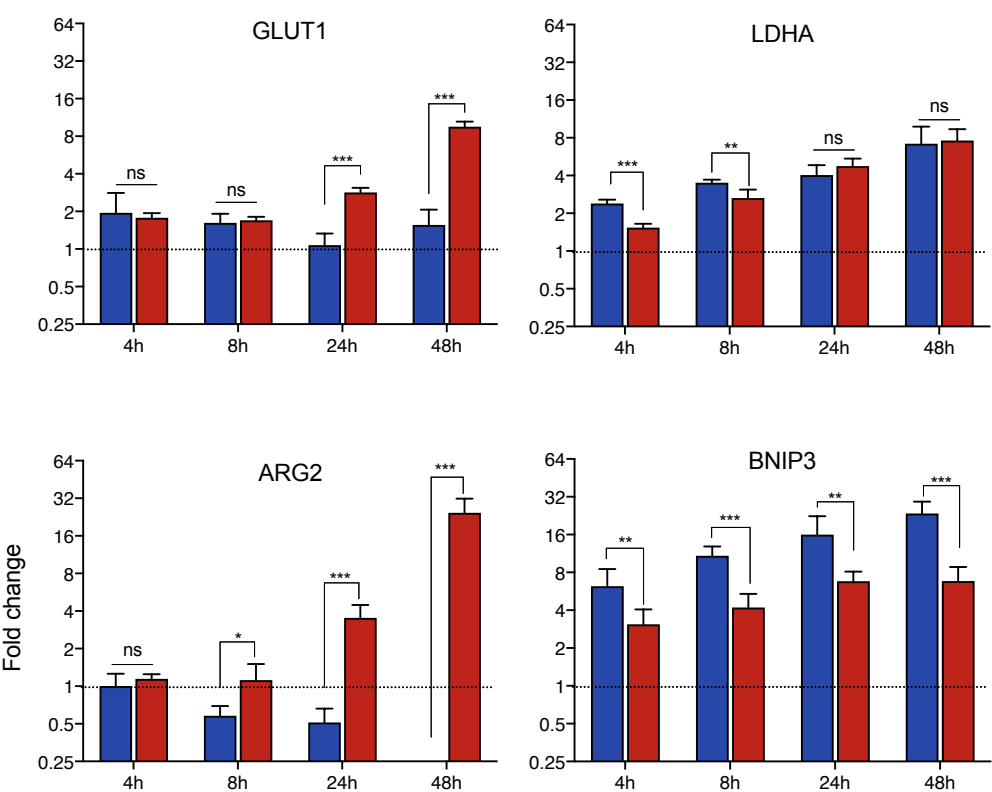
bioRxiv preprint doi: https://doi.org/10.1101/2020.08.25.265926; this version posted August 25, 2020. The copyright holder for this preprint (which was not certified by peer review) is the author/funder, who has granted bioRxiv a license to display the preprint in perpetuity. It is made available under aCC-BY-NC-ND 4.0 International license.

Organ-specific and $\mathrm{O}_{2}$-dependent endothelial hypoxia responses

Figure 1: Lung and brain MVEC show organ-specific response and tolerance to hypoxia

(A) Viability of MVECs exposed to $1 \% \mathrm{O}_{2}$ at $\mathrm{t}=0$, measured by propidium iodide staining $(\mathrm{n}=3)$; $\mathrm{t}$-tests corrected for multiple comparisons (Holm-Sidak) ${ }^{*} p<0.05,{ }^{* *} p<0.01, * * * p<0.005$ )

(B) Real-time viability of brain and lung MVECs exposed to $1 \% \mathrm{O} 2$ at $\mathrm{t}=0$, measured using the Real-Time Glo assay (Promega) ( $\mathrm{n}=3$ ). Shaded areas show SD, statistical differences were assessed by unpaired student's t-test, using the area under the curve $(* * * * p<0.0001)$.

(C,D) Western blot of HIF- $1 \alpha$ and HIF-2 $\alpha$ using nuclear extracts from brain and lung MVECs exposed to $1 \% \mathrm{O}_{2}$ for the indicated amount of time. Quantification for this blot is shown, and was normalized to loading control

(E) RT-qPCR for hypoxia targets PGK, VEGF, GLUT1, BNIP3, LDH-A, and HIF-2 $\alpha$ target ARG2 in brain and lung MVEC, at $21 \%, 10 \%$, or $5 \% \mathrm{O}_{2}$ baseline and after $1 \% \mathrm{O}_{2}$. Data is shown as average fold-change $\pm \mathrm{SD}$ (hypoxia/normoxia) ( $\mathrm{n}=3$ ). t-tests corrected for multiple comparisons (Holm-Sidak) using the log of fold change $* p<0.05,{ }^{* *} p<0.01, * * p<0.001$ )

appeared unable to mount a suitable adaptive response when transferred to hypoxia, even though for many tissues, including the brain, 1 \% $\mathrm{O}_{2}$ can still be considered physiological (Cater et al., 1961; Smith et al., 1977). Crucially, however, both organs contain much less oxygen than the $\mathrm{O}_{2}$ found in normobaric room air (Wenger et al., 2015), and thus the cellular responses observed at atmospheric oxygen tensions ( $21 \% \mathrm{O}_{2}$ ) are unlikely to represent physiological adaptations to hypoxia in the original tissue. To investigate this, primary MVEC were subsequently expanded in what was determined to be the best approximation to their typical physioxic state.

\section{Oxygen priming differentially conditions the hypoxia response of brain and lung MVEC}

MVEC were cultured at either $10 \%$ or $5 \% \mathrm{O}_{2}$ (physiological for lung and brain, respectively) in addition to standard $21 \% \mathrm{O}_{2}$, and hypoxia response evaluated for the same parameters as above. Upon transfer to $1 \%$ O2, both MVEC populations cultured in physioxia remined more viable than those primed at $21 \% \mathrm{O}_{2}$ (Figure 2A). HIF- $\alpha$ isoform levels were again assessed after $4 \mathrm{~h}$ of hypoxia and, as before, HIF-1 $\alpha$ signal was consistently higher in IMVEC than bMVEC, and this was significant when cells were expanded at $21 \%$ or $10 \%$ $\mathrm{O}_{2}$ (but not $5 \%$ ) prior to hypoxia. In both cell populations, HIF-1 $\alpha$ levels after hypoxia were highest if MVEC were cultured at $10 \% \mathrm{O}_{2}$ irrespective of their tissue of origin (Figure 2B); The quantification of HIF-1 $\alpha$ is shown in Figure 2C, where each data point refers to one biological replicate and dashed lines link lung and brain MVEC from the same experiment (and quantified from the same gel). Conversely, and similarly to what was shown in Figure 1D, HIF-2 $\alpha$ protein levels were higher in hypoxic bMVEC compared to IMVEC (Figure 2D); Quantification of hypoxic HIF-2 $\alpha$ signal is plotted in Figure 2E and, as above, signals from same experiment are linked by a dashed line. Significant differences between MVEC populations were only seen at the two highest $\mathrm{O}_{2}$ concentrations.

To investigate if these results reflected a change from the baseline HIF- $\alpha$ levels or were consistently high or low in specific MVEC populations, HIF protein levels before hypoxia were also quantified (Supplementary Figure S1A). Both isoforms were stable at physiological oxygen, underscoring their role in normal EC function; IMVEC has higher levels of HIF-1 $\alpha$, whereas HIF-2 $\alpha$ at baseline was low in both MVEC. Additionally, and to allow a direct assessment of HIF- $\alpha$ change of signal following hypoxia, hypoxic and physioxic nuclear protein extracts were run on the same gel (Supplementary Figure S1B, C), confirming that hypoxia induction of HIF-1 $\alpha$ 


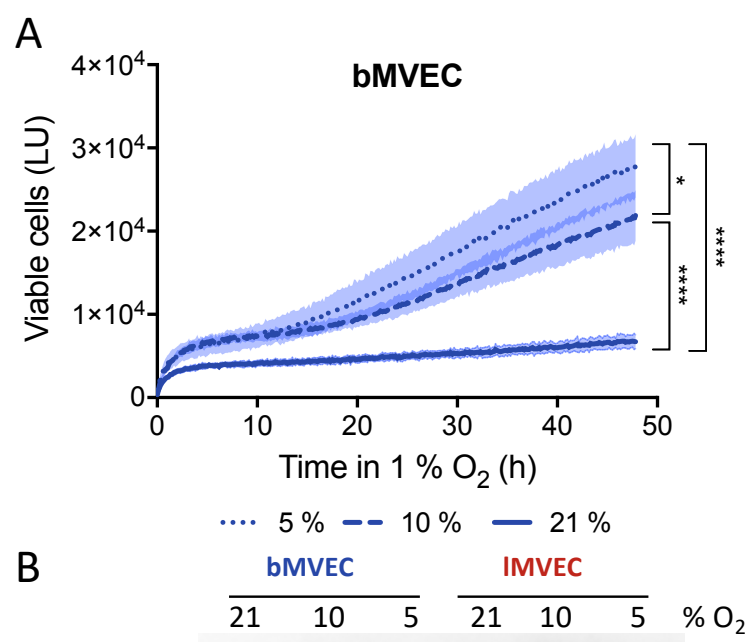

HIF-1 $\alpha$

$\beta$-actin

C

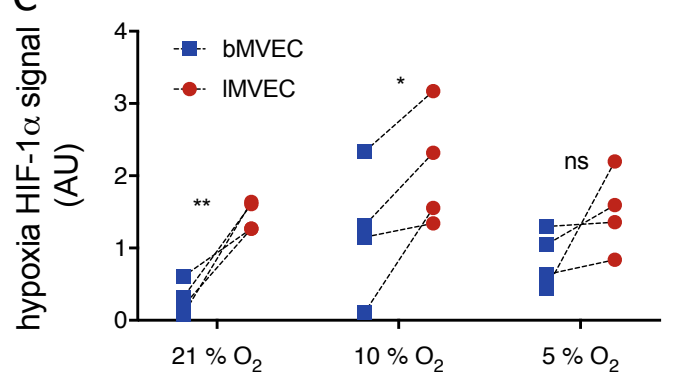

F
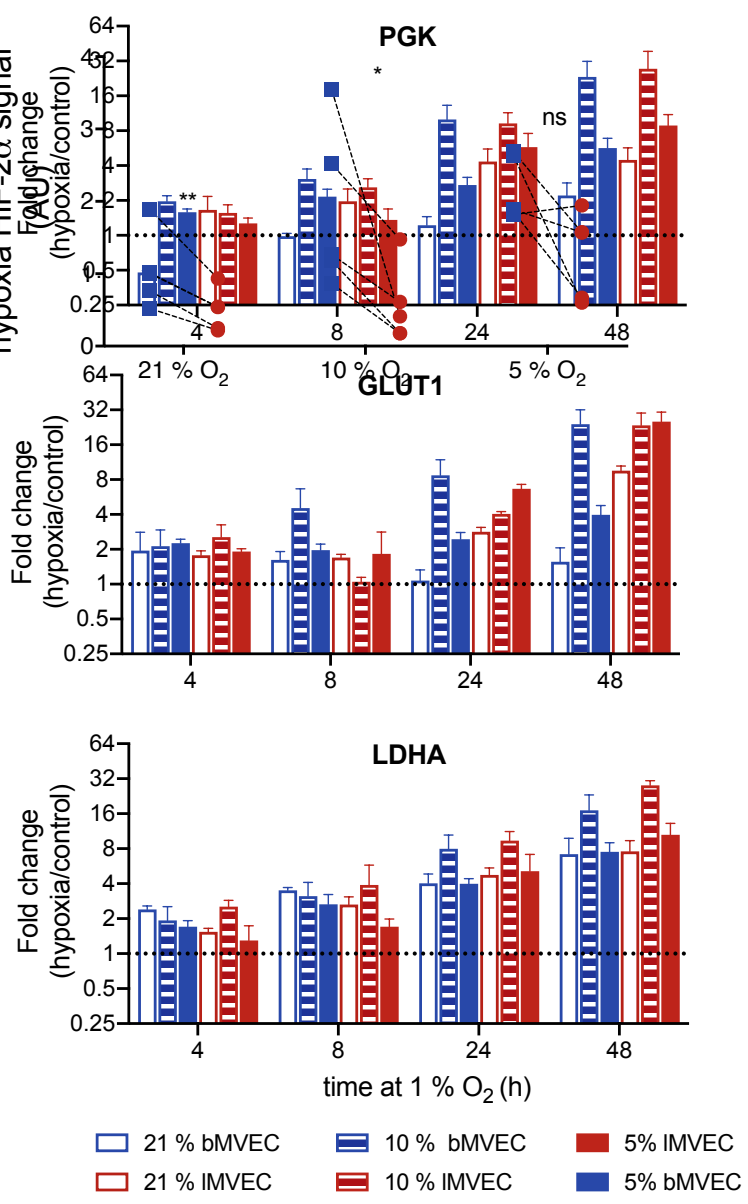
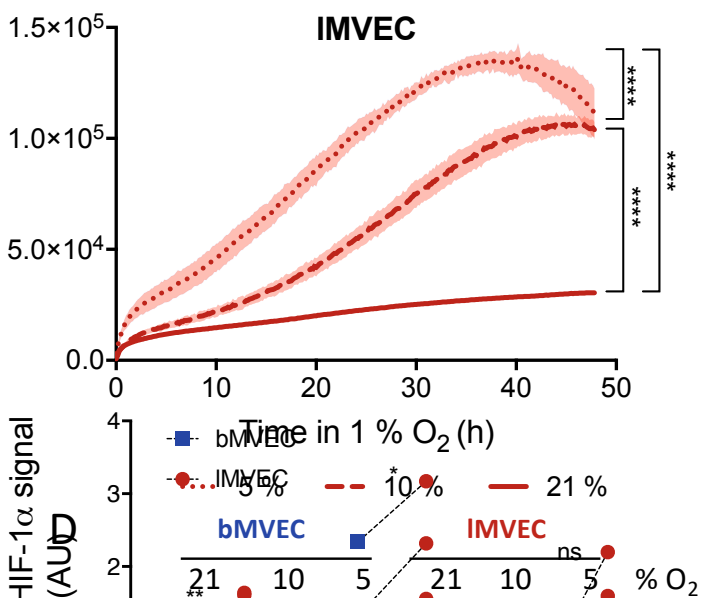

HIF- $2 \alpha$

$\beta$-actin
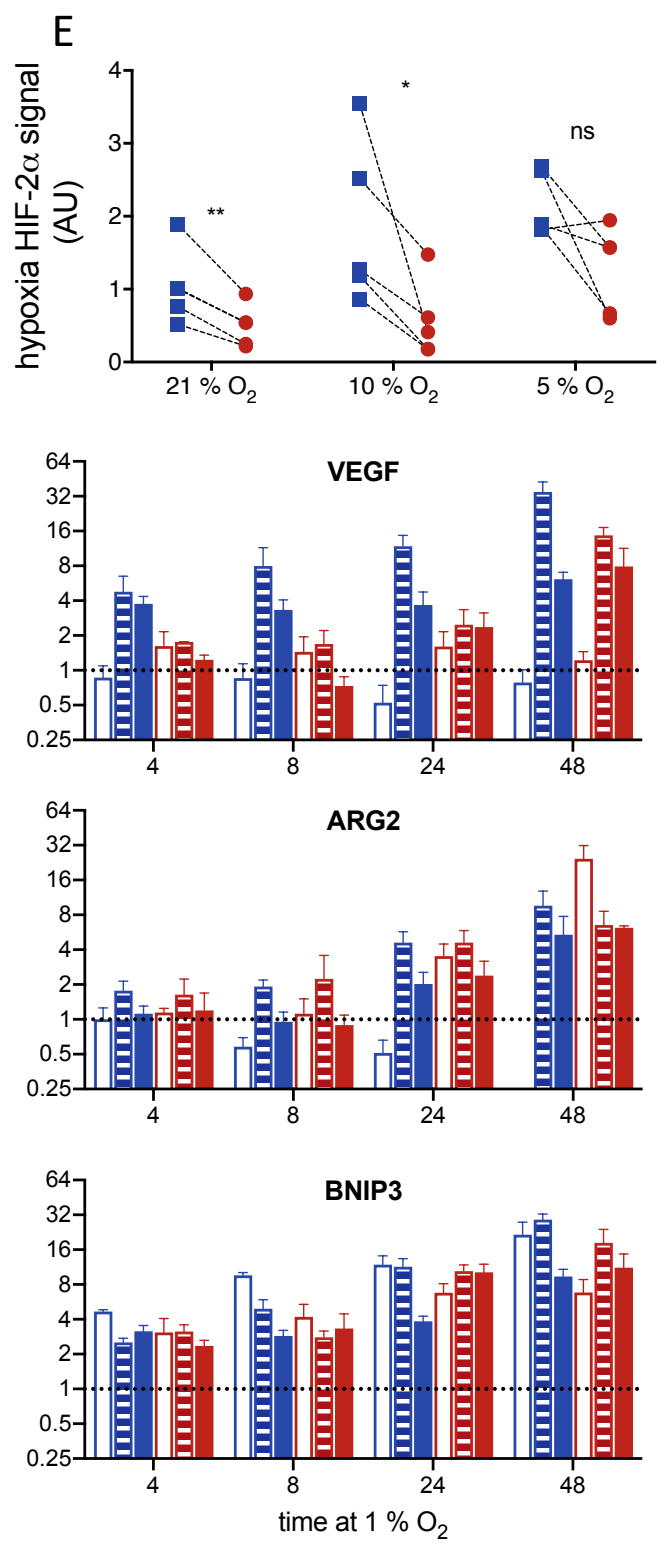
bioRxiv preprint doi: https://doi.org/10.1101/2020.08.25.265926; this version posted August 25, 2020. The copyright holder for this preprint (which was not certified by peer review) is the author/funder, who has granted bioRxiv a license to display the preprint in perpetuity. It is made available under aCC-BY-NC-ND 4.0 International license.

Organ-specific and $\mathrm{O}_{2}$-dependent endothelial hypoxia responses

Figure 2: MVEC response to hypoxia is organ-specific and dependent on $\mathrm{O}_{2}$ priming

(A) Real-time viability of brain (left, blue) and lung MVEC (right, red) maintained at $21 \%, 10 \%$, or $5 \% \mathrm{O}_{2}$ and exposed transferred to hypoxia $\left(1 \% \mathrm{O}_{2}\right)$ at $\mathrm{t}=0$ was measured using a Real-Time Glo assay (Promega) ( $\left.\mathrm{n}=3\right)$. Shaded areas show SD, statistical differences were assessed by 2-way ANOVA with Holm-Sidak's multiple comparison test, using the area under the curve $\left({ }^{*} p<0.05,{ }^{* * * *} p<0.0001\right)$.

(B) Representative western blot of HIF- $1 \alpha$ using nuclear extracts from brain and lung MVEC exposed to $1 \% \mathrm{O}_{2}$ for 4 h, and previously expanded at $21 \%, 10 \%$, or $5 \% \mathrm{O}_{2}$

(C) Quantification of HIF-1 $\alpha$ signal obtained by densitometry and normalized to the loading control; the lines connect samples from the same experiment ( $n=4$; paired t-test, ${ }^{*} p<0.05,{ }^{* *} p<0.01$ )

(D) Representative western blot of HIF-2 $\alpha$ using nuclear extracts from brain and lung MVEC exposed to $1 \% \mathrm{O}_{2}$ for $4 \mathrm{~h}$, and previously expanded at $21 \%, 10 \%$, or $5 \% \mathrm{O}_{2}$ (E) Quantification of HIF-2 $\alpha$ signal obtained by densitometry and normalized to the loading control; the lines connect samples from the same experiment ( $n=4$; paired t-test, ${ }^{*} p<0.05,{ }^{* *} p<0.01$ )

(F) RT-qPCR for hypoxia targets PGK, VEGF, GLUT1, BNIP3, LDH-A, and HIF-2 $\alpha$ target ARG2 in brain and lung MVEC, at $21 \%, 10 \%$, or $5 \% \mathrm{O}_{2}$ baseline and after $1 \% \mathrm{O}_{2}$. Data is shown as average fold-change $\pm \mathrm{SD}$ (hypoxia/baseline at $\left.4 \mathrm{~h}\right)(\mathrm{n}=3)$. Statistical differences were assessed by 2-way ANOVA with Holm-Sidak's multiple comparison test, using the log of fold change; the results of the statistical analysis are listed in Table S1.

occurs primarily in IMVEC, except when they are expanded at $5 \% \mathrm{O}_{2}$, indicating that this condition is subphysiological (or even hypoxic) for IMVEC. Contrary to the association of HIF-1 $\alpha$ activation with the early hypoxia response, $4 \mathrm{~h}$ of hypoxia led to preferential induction of HIF-2 $\alpha$ in bMVEC at physiological baseline $\mathrm{O}_{2}$, and to much higher levels than IMVEC induce HIF-1 $\alpha$. This is likely a result of elevated HIF-1 $\alpha$ levels in physioxic atmospheres. HIF-2 $\alpha$ induction in bMVEC was higher when cells were primed at lower $\mathrm{O}_{2}$, whereas HIF-1 $\alpha$ induction in IMVEC was lower. Conversely, HIF-1 $\alpha$ induction in bMVEC and HIF- $2 \alpha$ induction in IMVEC seem independent of baseline $\mathrm{O}_{2}$ (Supplementary Figure S1B, C).

Transcript levels of HIF targets are consistently more strongly upregulated in cells maintained in physiological $\mathrm{O}_{2}$ (Figure 2F, Supplementary Table S1). Most strikingly, VEGF and ARG2 mRNA levels were induced by hypoxia in bMVEC only if the cells had been cultured at $10 \%$ or $5 \% \mathrm{O}_{2}$. The autophagy marker BNIP3, however, was induced most strongly in bMVEC cultured at $21 \% \mathrm{O}_{2}$, correlating with their reduced survival to hypoxia in this condition. To extricate if the mRNA fold-change was skewed by transcript levels at baseline, the relative abundance of hypoxia-responsive transcripts before hypoxia treatment was plotted (Supplementary Figure S2). Indeed, some intrinsic differences are seen in the relative abundance of individual transcripts between the two MVEC populations, such as lower levels of LDH-A and VEGF in bMVEC. Baseline transcript levels were also different depending on $\mathrm{O}_{2}$ priming, and much higher GLUT1 levels in IMVEC maintained at $10 \% \mathrm{O}_{2}$. Overall, the largest increases in transcript levels of hypoxia response genes were generally seen in cells grown in physiological oxygen, especially at $10 \% \mathrm{O}_{2}$, and mostly for bMVEC.

To investigate if discrepancies were due to upstream regulation of HIF stabilisation (prolyl hydroxylases PHD13) or transcriptional activity (FIH) (Mahon et al., 2001; Lando, Peet, Gorman, et al., 2002), relevant protein levels were investigated by western blot (Supplementary Figure S3A). Protein levels of the canonical regulators of HIF were quantified, but no $\mathrm{O}_{2}$-dependent patterns or tissue-specific differences were seen to significantly differ between MVEC (Supplementary Figure S3A, S3B). PHD2 levels were slightly reduced in bMVEC at $10 \%$ and $5 \% \mathrm{O}_{2}$, and PHD3 was consistently higher in those cells, in all $\mathrm{O}_{2}$ conditions, compared to IMVEC. FIH 
bioRxiv preprint doi: https://doi.org/10.1101/2020.08.25.265926; this version posted August 25, 2020. The copyright holder for this preprint (which was not certified by peer review) is the author/funder, who has granted bioRxiv a license to display the preprint in perpetuity. It is made available under aCC-BY-NC-ND 4.0 International license.

Organ-specific and $\mathrm{O}_{2}$-dependent endothelial hypoxia responses

expression was significantly elevated in MVEC maintained in $21 \% \mathrm{O}_{2}$, irrespective of tissue of origin. While these results may not explain the HIF isoform levels, it may contribute to the dampened hypoxia response of MVEC cultured in hyperoxia. The levels of HIF- $\alpha$ mRNA were also measured (Supplementary Figure S2B), and almost entirely reflect the baseline protein abundance quantified by WB, despite the traditional assumption that HIF is mostly post-translationally regulated. However, IMVEC grown at $21 \% \mathrm{O}_{2}$ displayed much lower levels of HIF-1 $\alpha$ mRNA than any other sample, a trend not reflected at the protein level.

The data above shows that MVEC viability is affected by oxygen priming, yet even though HIF- $\alpha$ isoform activation is tissue-specific, it does not appear to affect HIF-dependent transcriptional activation of hypoxiarelated targets, or viability when cells are primed in physioxia, and as such the different tolerance seen between lung and brain MVEC appear largely independent from HIF stabilization.

\section{Glycolytic activity of MVEC is altered as a result of oxygen priming}

Endothelial metabolism has been shown to underlie endothelial function, and EC are widely believed to be consistently and intrinsically glycolytic (Krützfeldt et al., 1990). However, a further shift towards glycolysis is key to enable adaptation and survival to hypoxic conditions. Glycolytic stress tests were performed to compare glycolytic metabolism in MVEC from brain and lung tissues, using extracellular acidification rate (ECAR) as a readout of glycolytic activity at baseline and upon complete mitochondrial inhibition with Oligomycin (maximal capacity) (Teslaa and Teitell, 2014). Representative graphs are shown in Figure 3A, and summaries of average glycolytic parameters quantified in the two MVEC populations are presented in Figure 3B. Baseline glycolysis, as expected, was higher in cells maintained in environments with lower $\mathrm{O}_{2}$. Although maximal glycolytic capacity (and thus spare capacity) was comparable between the two MVEC at all $\mathrm{O}_{2}$ tensions, IMVEC had slightly but significantly higher basal glycolytic activity at physiological $\mathrm{O}_{2}$ tensions than bMVEC (Figure 3B).

Changes in glycolytic function following adaptation to hypoxia were subsequently assessed (Figure 3C, D). Here, cells expanded in the three different oxygen environments were transferred to $1 \% \mathrm{O}_{2}$ for $24 \mathrm{~h}$ prior to the assay, to stabilise any metabolic changes resulting from adaptation to hypoxia. Cell viability was confirmed and cell density optimised for each MVEC population (see methods), to avoid assaying non-viable cells or induce anoxia in assay wells. Adaptation to hypoxia in terms of glycolytic activity is both oxygen-dependent and organ-specific (Figure 3C). IMVEC maintained an inverse correlation between $\mathrm{O}_{2}$ levels and glycolytic rates seen at baseline (Figure 3B); following adaptation to hypoxia, IMVEC showed a basal glycolytic rate lower than that of bMVEC if the cells had been grown at $21 \%$, similar if the cells had been grown at $10 \%$, and higher if the cells had been grown at $5 \% \mathrm{O}_{2}$ (Figure 3D). Interestingly, hypoxic bMVEC had a larger glycolytic spare capacity following $24 \mathrm{~h}$ of hypoxia in all condittions (significant at higher $\mathrm{O}_{2}$ levels). Indeed, bMVEC are much more likely to encounter such low levels of oxygen in vivo, and as such, by maintaining glycolytic plasticity, would be better equipped to adjust to low $\mathrm{O}_{2}$. This, however, is in stark contrast with the fact that bMVEC are more susceptible to hypoxia, albeit only when primed at $21 \% \mathrm{O}_{2}$ (Figures 1, 2). 
bioRxiv preprint doi: https://doi.org/10.1101/2020.08.25.265926; this version posted August 25,2020 . The copyright holder for this preprint (which was not certified by peer review) is the author/funder, who has granted bioRxiv a license to display the preprint in perpetuity. It is made available under aCC-BY-NC-ND 4.0 International license.

Organ-specific and $\mathrm{O}_{2}$-dependent endothelial hypoxia responses

A

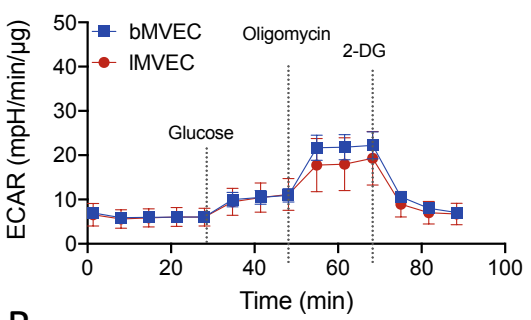

B

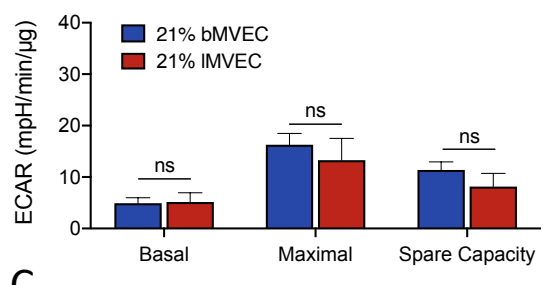

C
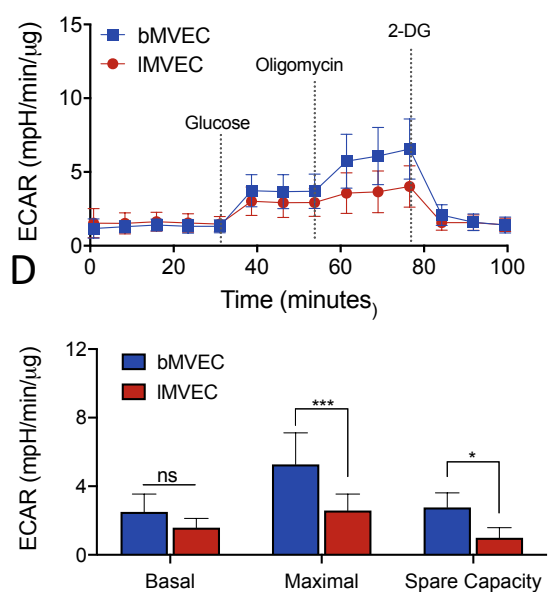

$10 \% \mathrm{O}_{2}$
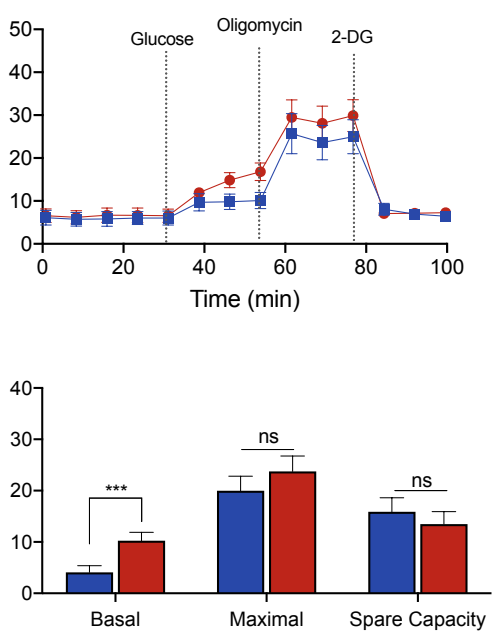

Basal
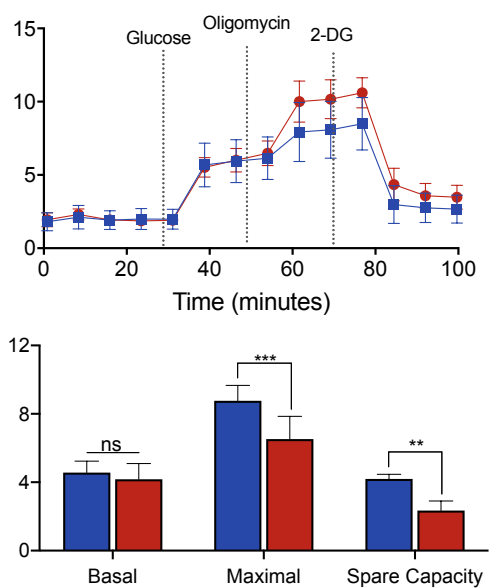

$5 \% \mathrm{O}_{2}$
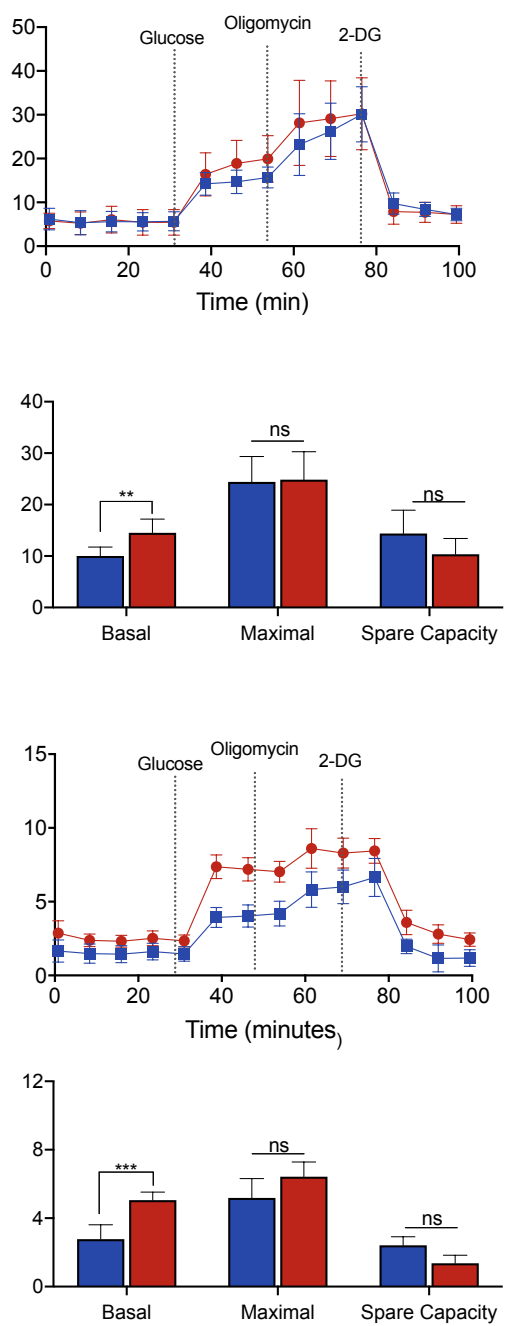

Figure 3: MVEC glycolytic activity is organ-specific and affected by $\mathrm{O}_{2}$ priming

(A) Representative charts of baseline glycolytic stress tests of brain and lung MVEC cultured at $21 \% \mathrm{O}_{2}$ (left), $10 \% \mathrm{O}_{2}$ (middle), or 5 $\% \mathrm{O}_{2}$ (right).

(B) Glycolytic parameters calculated from each curve from (A) are shown as average $\pm S D(n \geq 4)$. Statistical analysis was done using 2-way ANOVA with Holm-Sidak's multiple comparison test $\left({ }^{*} p<0.05,{ }^{* *} p<0.01,{ }^{* * *}<0.001\right)$

(C) Representative charts of glycolytic stress tests of brain and lung MVEC after 24 h of hypoxia $\left(1 \% \mathrm{O}_{2}\right)$, from cells primed at different $\mathrm{O}_{2}$; assays were carried out at $1 \% \mathrm{O}_{2}$

(D) Glycolytic parameters calculated from each curve from (C) are shown as average $\pm S D(n \geq 4)$. Statistical analysis was done using 2-way ANOVA with Holm-Sidak's multiple comparison test $\left({ }^{*} p<0.05,{ }^{* *} p<0.01,{ }^{* * *}<0.001\right)$

To further investigate this conundrum, ECAR was measured immediately upon transfer to $1 \% \mathrm{O}_{2}$, such that the glycolytic shift could be observed in real-time, instead of allowing the cells $24 \mathrm{~h}$ to adjust. This revealed that oxygen priming drastically affects MVEC adaptation to hypoxia (Figure 4A), both in terms of timing and amplitude (note y-axis matched scale). Both MVEC grown in $21 \% \mathrm{O}_{2}$ (left) showed a very mild increase in ECAR, which was further delayed in bMVEC. If primed at $10 \% \mathrm{O}_{2}$ (middle), IMVEC increased glycolytic activity within the first $5 \mathrm{~h}$, to more than 2 -fold than the same cell population expanded at $21 \% \mathrm{O}_{2}$. For the same conditions (21\% and 10\%), increase in ECAR for bMVEC upon hypoxia exposure was still very mild. However, when MVEC 
bioRxiv preprint doi: https://doi.org/10.1101/2020.08.25.265926; this version posted August 25,2020 . The copyright holder for this preprint (which was not certified by peer review) is the author/funder, who has granted bioRxiv a license to display the preprint in perpetuity. It is made available under aCC-BY-NC-ND 4.0 International license.

Organ-specific and $\mathrm{O}_{2}$-dependent endothelial hypoxia responses

A

$21 \% \mathrm{O}_{2}$

$10 \% \mathrm{O}_{2}$

$5 \% \mathrm{O}_{2}$

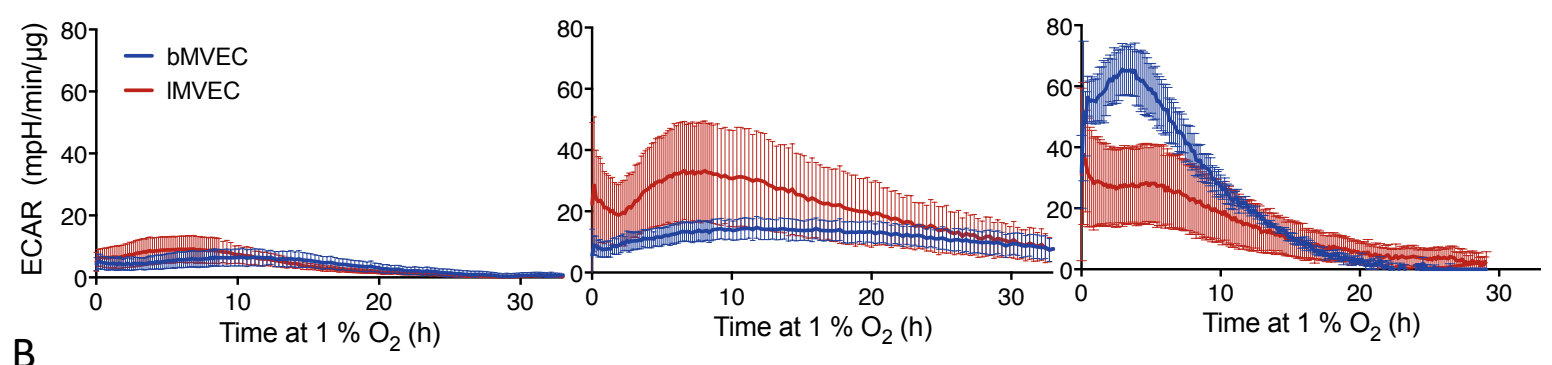

B
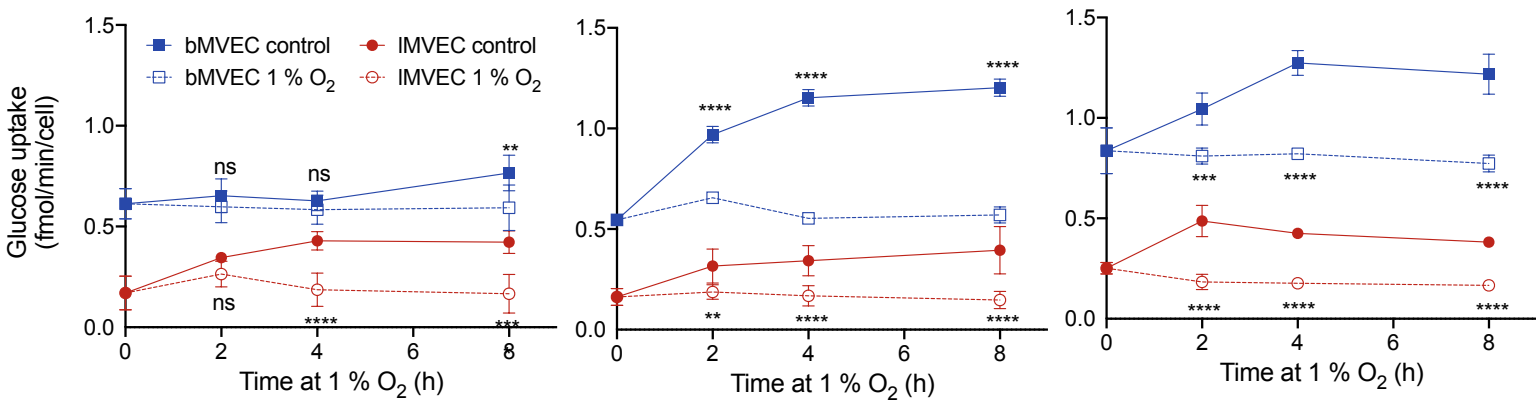

C
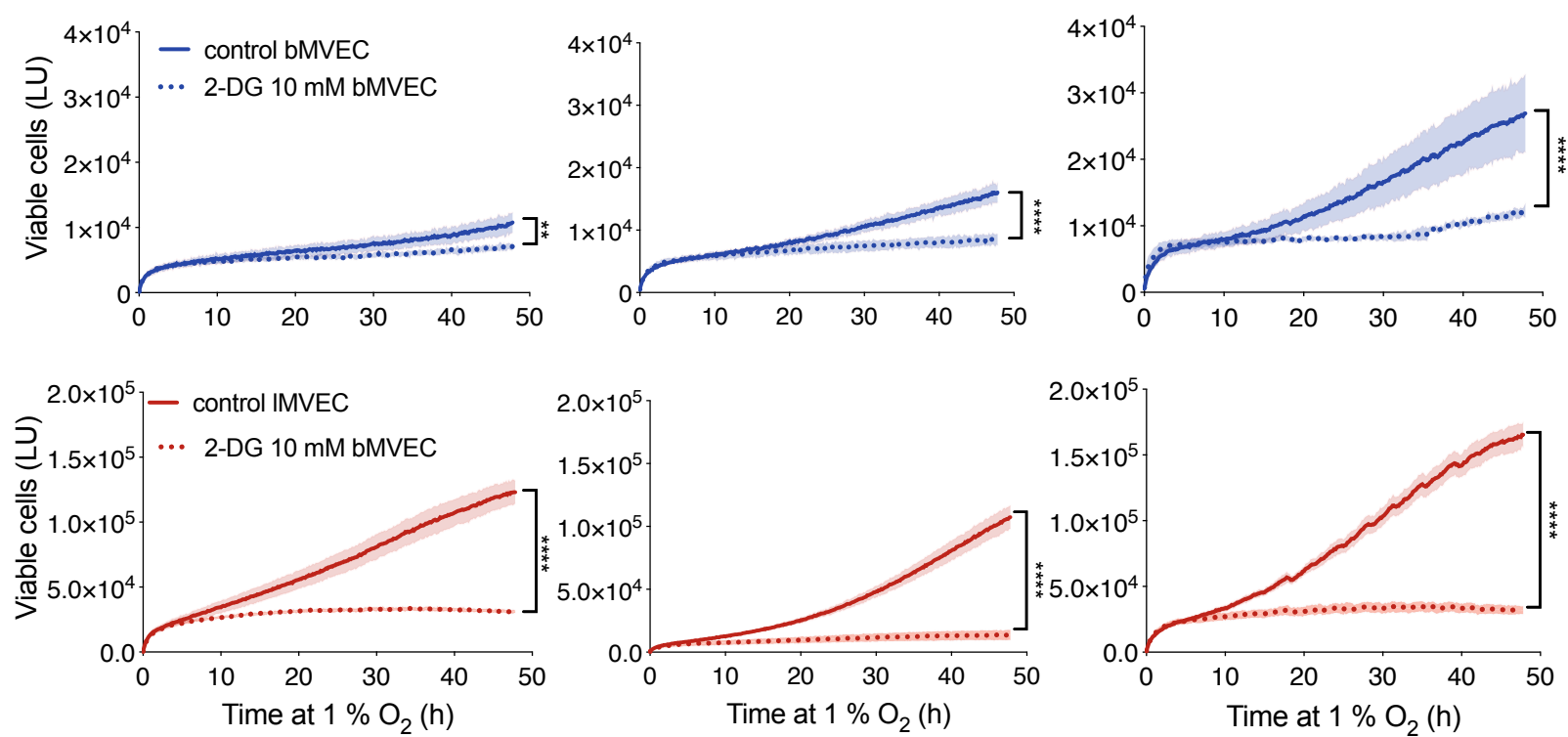

Figure 4: Timing and amplitude of metabolic shift to glycolysis is organ-specific and oxygen-dependent

(A) Representative charts of real-time measurement of ECAR changes upon transfer to $1 \% \mathrm{O}_{2}$ at $\mathrm{t}=0$, in lung and brain MVEC previously expanded at different $\mathrm{O}_{2}$ levels $\left(21 \% \mathrm{O}_{2}\right.$, left), $10 \% \mathrm{O}_{2}$, middle, or $5 \% \mathrm{O}_{2}$, right) $(\mathrm{n} \geq 4)$

(B) Glucose uptake in MVEC expanded at different $\mathrm{O}_{2}$ levels at baseline (dashed line) or under hypoxia (solid line), was measured at the indicated times using the Glucose Uptake-Glo assay (Promega) Data shown as average \pm SD, and statistical differences were assessed by 2-way ANOVA with Holm-Sidak's multiple comparison test (**p<0.01, $\left.{ }^{* * *}<0.001, * * * * p<0.0001\right), \mathrm{n}=3$.

(C) Real-time viability of brain (top, blue) and lung (bottom, red) was assessed every 10 min using a Real-Time Glo assay (Promega) in MVEC transferred to $1 \% \mathrm{O}_{2}$ at $\mathrm{t}=0$ and treated with $10 \mathrm{mM}$ 2-deoxy glucose (dotted line) or PBS vehicle control (solid line). N=6 for each condition. Shaded areas show SD, statistical differences were assessed by unpaired student's t-test, corrected for multiple comparisons (Holm-Sidak) using the area under the curve $\left({ }^{* *} p<0.01,{ }^{* * * *} p<0.0001\right)$.

were maintained at $5 \% \mathrm{O}_{2}$ prior to hypoxia (right), the ECAR measured in bMVEC increased within minutes, to an extraordinary extent, highest seen for either cell type in any condition. This experiment demonstrates that bMVEC are significantly more responsive to hypoxia, but only if kept in physioxia. On the other hand, 
bioRxiv preprint doi: https://doi.org/10.1101/2020.08.25.265926; this version posted August 25, 2020. The copyright holder for this preprint (which was not certified by peer review) is the author/funder, who has granted bioRxiv a license to display the preprint in perpetuity. It is made available under aCC-BY-NC-ND 4.0 International license.

Organ-specific and $\mathrm{O}_{2}$-dependent endothelial hypoxia responses

IMVEC moved from $5 \%$ to $1 \% \mathrm{O}_{2}$ are unable to further increase ECAR, corroborating that $5 \% \mathrm{O}_{2}$ is already seen as hypoxia by these cells.

Glucose uptake assays were also performed in real time (Figure 4B). This experiment revealed that bMVEC have intrinsically higher rates of glucose uptake than IMVEC, irrespective of $\mathrm{O}_{2}$ availability (Figure 4B, Supplementary Figure S4A), or indeed GLUT1 transcript levels (Figure 1E, 2F, Supplementary Figure S2). As expected, glucose uptake increases in all MVEC upon transfer to hypoxia (Figure 4B), except in bMVEC primed at $21 \% \mathrm{O}_{2}$ (Figure 4B, left), which appear inept at increasing glucose uptake until $8 \mathrm{~h}$ after hypoxia exposure. Glucose uptake is an essential step in triggering a concomitant increase in glycolytic activity, and is in agreement with the data Figure 4A (left), showing bMVEC have a delayed perception of $\mathrm{O}_{2}$ levels when maintained in $21 \% \mathrm{O}_{2}$.

Viability assays performed in the presence of $10 \mathrm{mM}$ 2-DG, a competitive inhibitor of glycolysis were performed to investigate if the increased hypoxic viability of MVEC grown at lower oxygen levels was indeed due to dependence on glycolytic metabolism. Removing the ability to use glucose for cellular energetic demands under hypoxia resulted in arrest of proliferation, irrespective of the glycolytic reserve of each MVEC population or culture condition (Figure 4C).

Combined, the results shown above strongly suggest that high oxygen levels impair MVEC perception of, and therefore response to, a hypoxic challenge, and this is more striking in MVEC that originate from brain tissue.

\section{Effects of oxygen priming on mitochondrial respiration}

Following the assessment of glycolytic capacity and response in different MVEC populations, the effect on mitochondrial metabolism was investigated and compared as a function of oxygen availability. Oxygen consumption rates (OCR) were calculated from mitochondrial stress tests. Mitochondrial basal and maximal respiration rates, predictably, directly correlated with oxygen levels in both MVEC: those grown at $21 \% \mathrm{O}_{2}$ have the highest OCR, whereas those maintained at $5 \% \mathrm{O}_{2}$ were the least reliant on mitochondrial respiration, as their metabolic preference is, naturally, glycolysis (Figure 5A, note mismatched y-axis scales, and Figure 5B). This pattern was considerably more pronounced in IMVEC, and as a result the maximal OCR of IMVEC grown at $21 \% \mathrm{O}_{2}$ was higher than that of bMVEC (Figure 5A,B left), whereas at 5\% $\mathrm{O}_{2}$ that pattern was strikingly reversed (Figure 5A, B, right), and bMVEC retained a proportionally higher mitochondrial reserve. At $10 \% \mathrm{O}_{2}$ (Figure 5A,B, middle panels) there was no difference between the two MVEC populations. Thus, at physiological $\mathrm{O}_{2}$, bMVEC maintain higher relative mitochondrial spare capacity than their lung counterparts.

Mitochondrial respiration parameters were assessed also following $24 \mathrm{~h}$ at $1 \% \mathrm{O}_{2}$. Similarly to what was seen at baseline (prior to hypoxia), basal respiration rates were identical between the two MVEC populations primed at $21 \% \mathrm{O}_{2}$ (Figure 5C, D, left). Maximal respiration was seen to decrease only in IMVEC, whereas bMVEC grown in physiological $\mathrm{O}_{2}$ retained a significantly higher maximal respiration rate compared to IMVEC (Figure 5C, D, middle and right panels). 
bioRxiv preprint doi: https://doi.org/10.1101/2020.08.25.265926; this version posted August 25,2020 . The copyright holder for this preprint (which was not certified by peer review) is the author/funder, who has granted bioRxiv a license to display the preprint in perpetuity. It is made available under aCC-BY-NC-ND 4.0 International license.

Organ-specific and $\mathrm{O}_{2}$-dependent endothelial hypoxia responses

$21 \% \mathrm{O}_{2}$

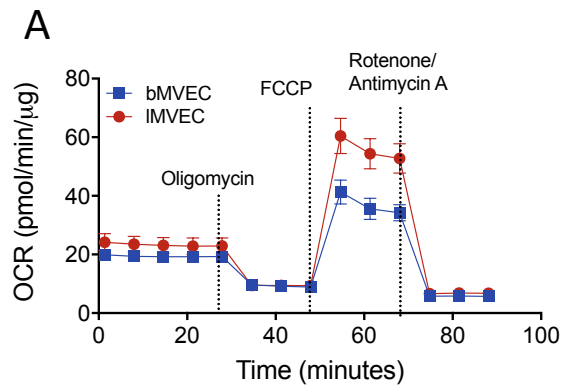

B

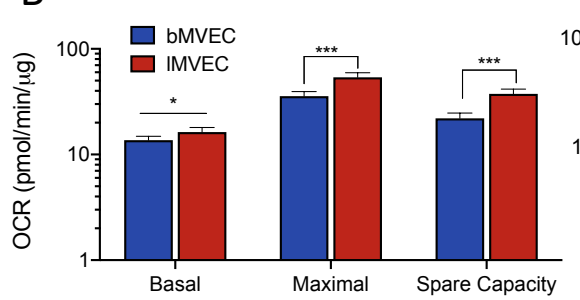

$10 \% \mathrm{O}_{2}$
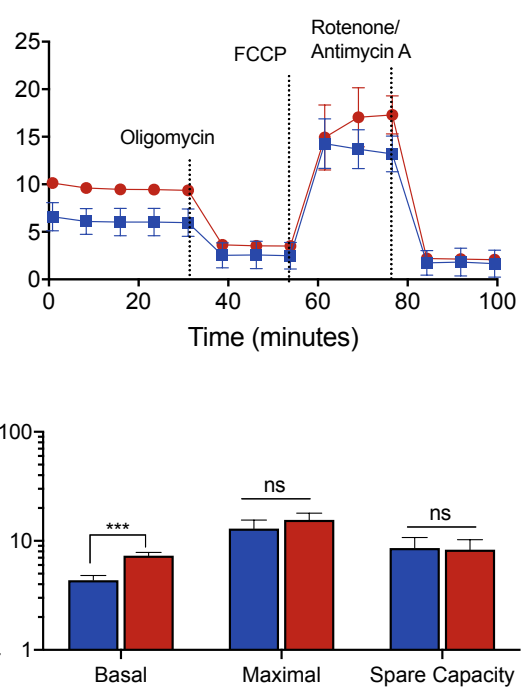

$5 \% \mathrm{O}_{2}$
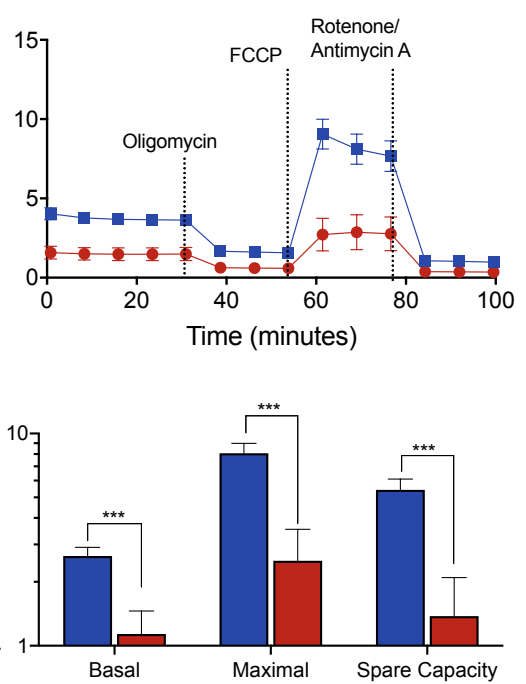

C
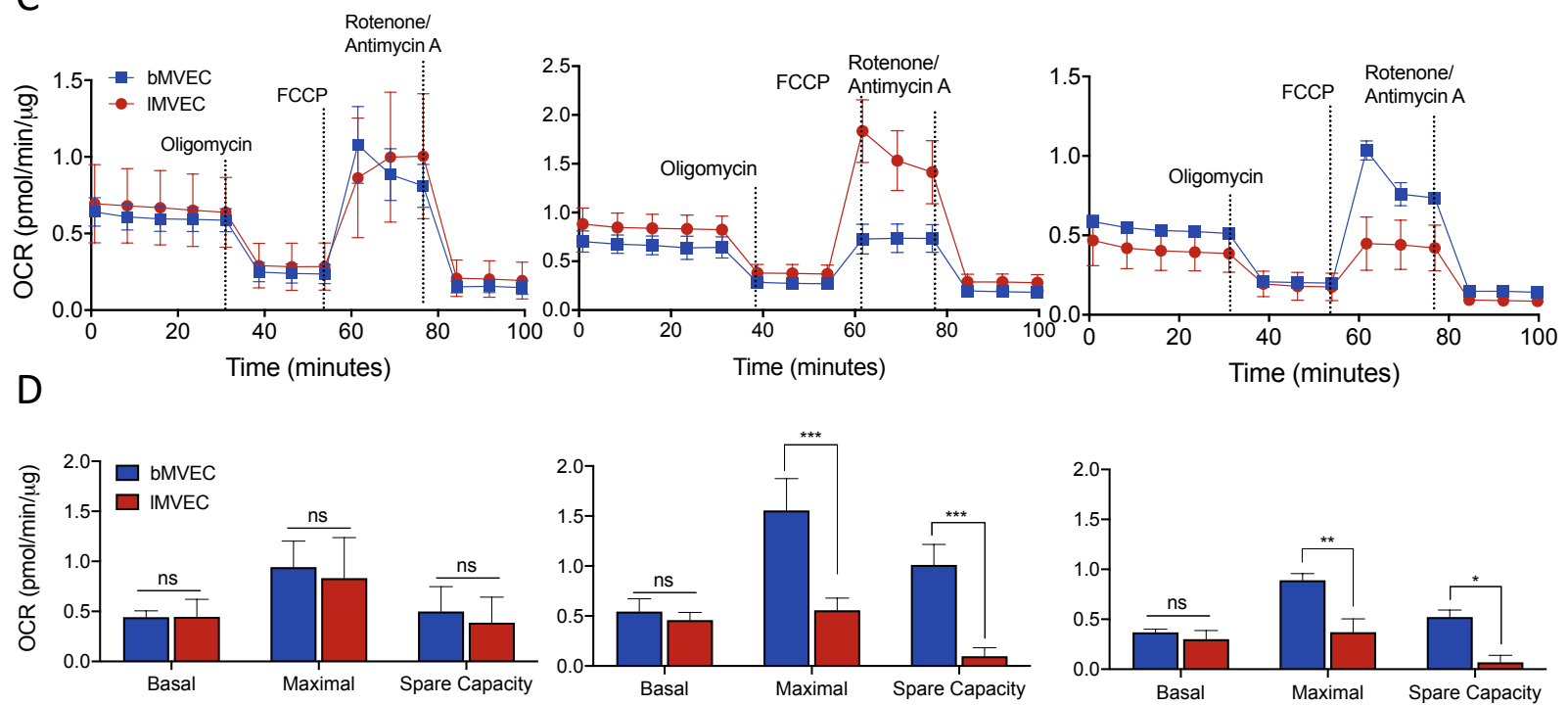

Figure 5: Mitochondrial metabolism of MVEC at baseline and after hypoxia is conditioned by oxygen priming and organ of origin

(A) Representative charts of mitochondrial function at baseline, in MVEC cultured at different $\mathrm{O}_{2}\left(21 \%\right.$, left, $10 \% \mathrm{O}_{2}$ middle, or $5 \%$ $\mathrm{O}_{2}$ right)

(B) Mitochondrial metabolic parameters were calculated from each curve from (A). Data are shown as average \pm SD ( $n \geq 4)$, statistical analysis was done using multiple t-tests with Holm-Sidak's multiple comparison test $\left({ }^{*} p<0.05,{ }^{* *} p<0.01,{ }^{* * *}<0.001\right)$

(C) Representative charts of mitochondrial function after adaptation to hypoxia ( $1 \% \mathrm{O}_{2}$ for $24 \mathrm{~h}$ prior to start of the assay). Assays were carried out at $1 \% \mathrm{O}_{2}$

(D) Mitochondrial metabolic parameters of assays carried out after hypoxia were calculated from each curve from (C). Data are shown as average $\pm S D(n \geq 4)$, Significance assessed with 2-way ANOVA with Holm-Sidak's multiple comparison test $\left({ }^{*} p<0.05,{ }^{* *} p<0.01\right.$, $* * *<0.001)$

These data indicate that bMVEC have wider metabolic plasticity, and overall higher mitochondrial activity than their lung counterparts. However, it is also apparent that bMVEC are more vulnerable to high oxygen levels. To confirm that the EC metabolic profile is reflected in functional aspects of MVEC behaviour, a migration assay was performed to assess alterations in EC function as a result of $\mathrm{O}_{2}$ priming (Supplementary Figure 4B, 
bioRxiv preprint doi: https://doi.org/10.1101/2020.08.25.265926; this version posted August 25, 2020. The copyright holder for this preprint (which was not certified by peer review) is the author/funder, who has granted bioRxiv a license to display the preprint in perpetuity. It is made available under aCC-BY-NC-ND 4.0 International license.

Organ-specific and $\mathrm{O}_{2}$-dependent endothelial hypoxia responses

C). This was done in the absence (Supplementary Figure 4B) and presence of the proliferation inhibitor Mitomycin C (MM) (Chen et al., 2013) (Supplementary Figure 4C,D), thus discriminating closure due to proliferation and migration, or migration alone, respectively. MVEC maintained in their respective physioxia closed the scratch wound more effectively than in either of the alternative atmospheres, and were slowest to migrate when in hyperoxia. bMVEC were generally less motile than those from lung, and the effect of $\mathrm{O}_{2}$ preconditioning was less pronounced; also, and seeing that the fastest closure occurred in cells at $5 \% \mathrm{O}_{2}$ suggests that bMVEC are intrinsically less migratory, and rely more on cell division for wound closure than do IMVEC, which appear generally less susceptible to the presence of MM.

\section{Effects of $\mathrm{O}_{2}$ on mitochondrial ETC complexes is organ-specific}

Having investigated the effects of varying oxygen levels on mitochondrial metabolism, the impact on the mitochondrial ETC composition was further investigated. Total protein was isolated from bMVEC and IMVEC at baseline and following $24 \mathrm{~h}$ of adaptation to $1 \% \mathrm{O}_{2}$, for each oxygen condition. These were resolved by SDSPAGE, probed with a mitochondrial ETC antibody cocktail (Sim et al., 2018) and quantified upon normalization against a positive control (Figure 6). A representative blot of IMVEC protein (Figure 6A) and the ratio of signal for each complex was compared to that seen at $21 \% \mathrm{O}_{2}$ (Figure 6B). In IMVEC, there was a positive (and expected) correlation between oxygen levels and mitochondrial complex protein levels; cells grown at lower $\mathrm{O}_{2}$ had lower levels of mitochondrial ETC complexes than cells grown at $21 \% \mathrm{O}_{2}$. This was further (and in most cases, significantly) exacerbated in MVEC following adaptation to $1 \% \mathrm{O}_{2}$ for $24 \mathrm{~h}$ (shaded areas), mostly in those cells previously maintained in physioxia.

A very different pattern was seen in MVEC that originated from brain tissue (Figure 6C); instead of a general decrease in protein from all ETC complexes, bMVEC cultured at $10 \%$ or $5 \% \mathrm{O}_{2}$ have much higher levels of Complex II, which increased following hypoxia exposure (Figure 6C,D). Notably, if MVEC were kept in hyperoxia $\left(21 \% \mathrm{O}_{2}\right.$ ), complex II levels were not changed by hypoxia (Figure 6D). The activity of succinate dehydrogenase (SDH, complex II) (Figure 6E) as well as succinate levels (Figure 6F) were quantified at baseline and following adaptation to hypoxia, in MVEC primed in their own physiological oxygen and compared to those maintained in normal atmosphere. In bMVEC, SDH activity correlated with SDH protein levels shown in Figure 6C,D, and a striking and inverse correlation with succinate levels, which accumulate to significantly higher concentrations in cells from $21 \% \mathrm{O}_{2}$, both at baseline and after hypoxia. Physioxic (but not hyperoxic) IMVEC, SDH activity is not affected by culture conditions or hypoxia, but succinate levels (Figure 6F) slightly increase following hypoxia. Interestingly, both baseline levels and the extent of accumulation are an order of magnitude lower than what is seen in bMVEC (note split scales). These data suggest that mitochondria from hyperoxic bMVEC lose SDH protein and activity, and as a result accumulate extremely high (and potentially toxic) levels of 
bioRxiv preprint doi: https://doi.org/10.1101/2020.08.25.265926; this version posted August 25,2020 . The copyright holder for this preprint (which was not certified by peer review) is the author/funder, who has granted bioRxiv a license to display the preprint in perpetuity. It is made available under aCC-BY-NC-ND 4.0 International license.

Organ-specific and $\mathrm{O}_{2}$-dependent endothelial hypoxia responses
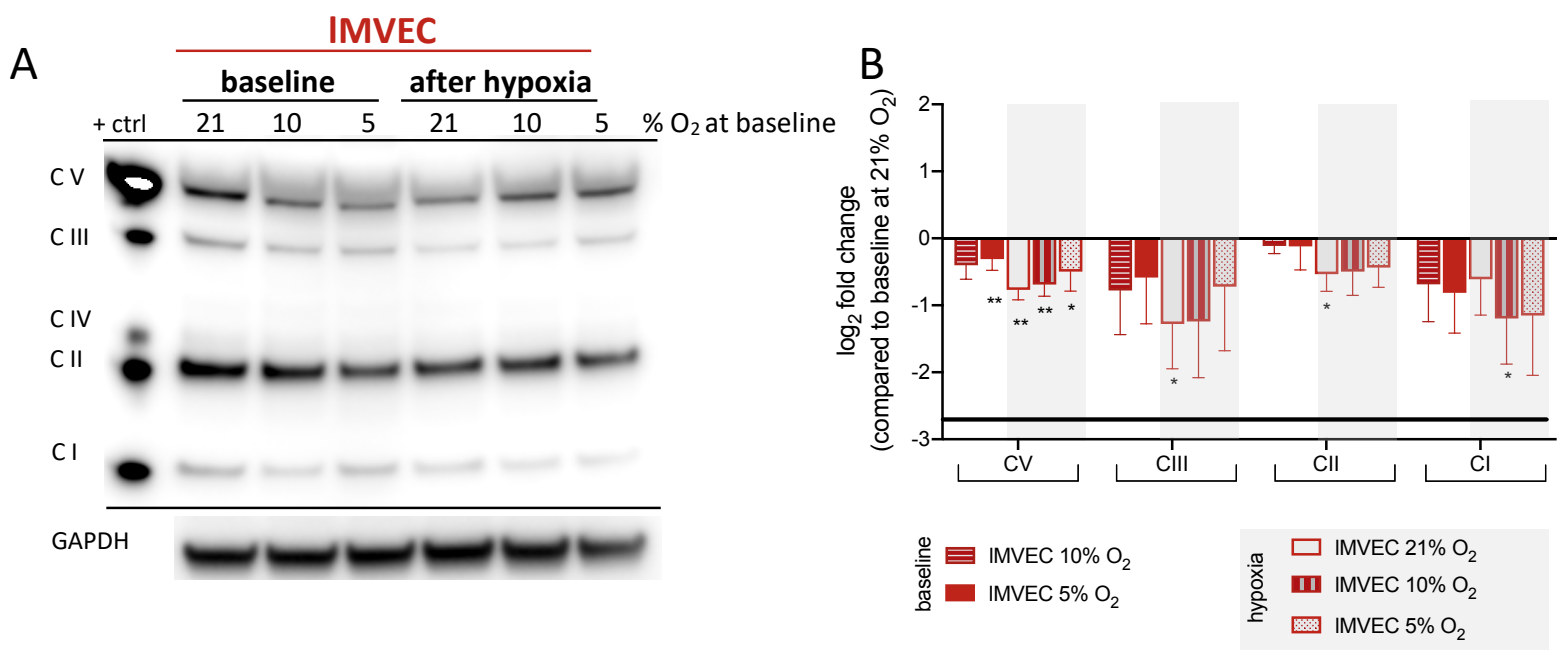

bMVEC

C

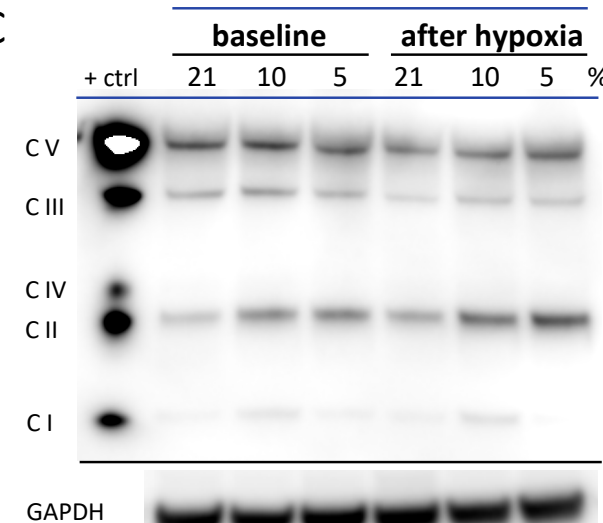

E
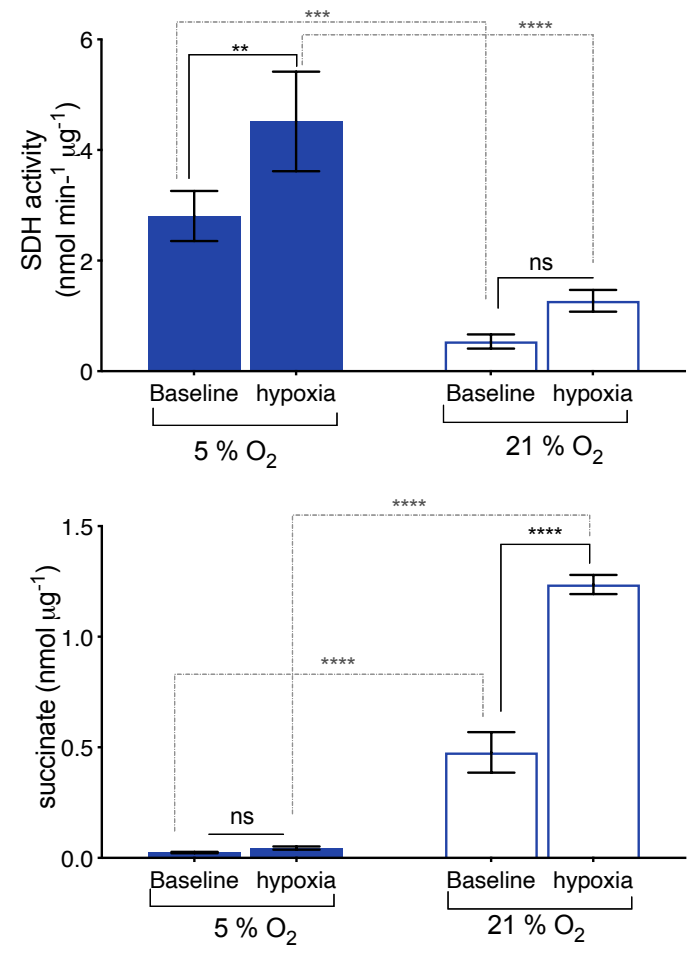

D

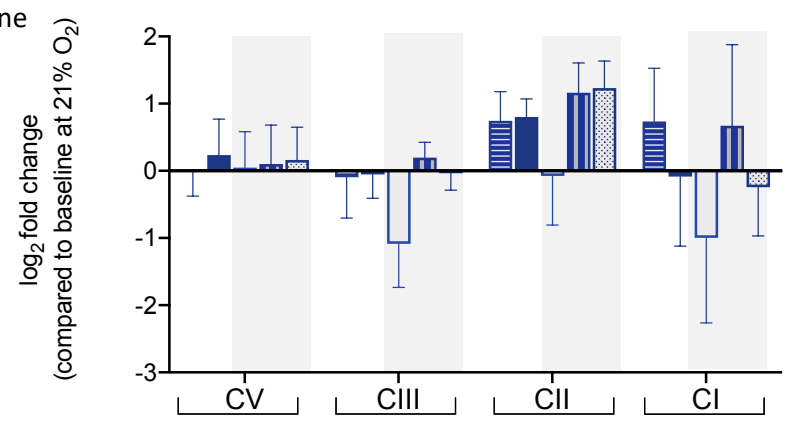

F

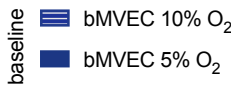

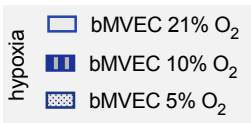
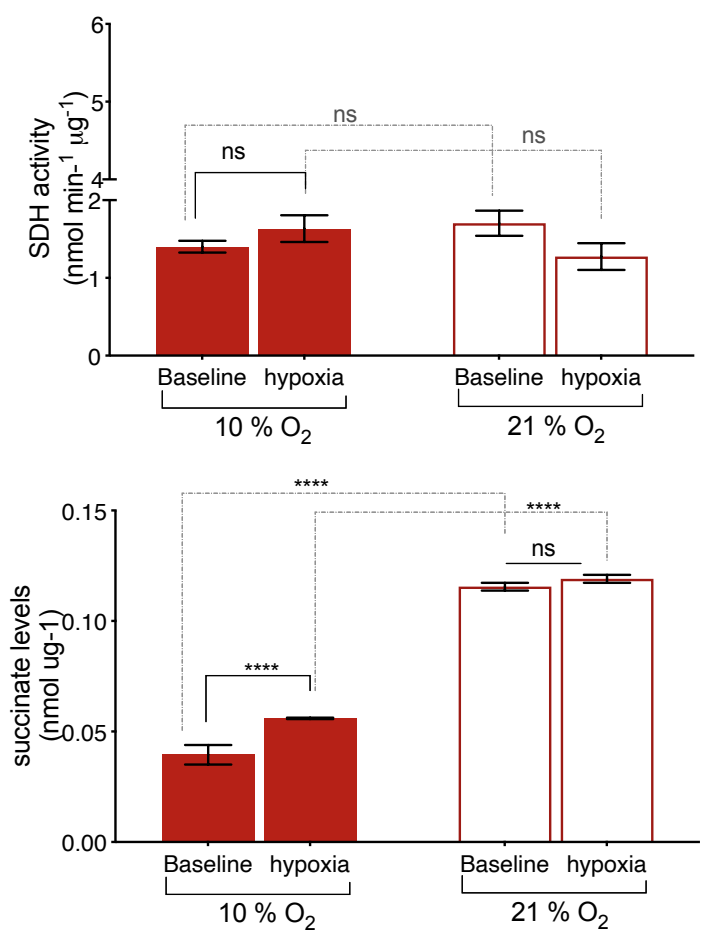
bioRxiv preprint doi: https://doi.org/10.1101/2020.08.25.265926; this version posted August 25, 2020. The copyright holder for this preprint (which was not certified by peer review) is the author/funder, who has granted bioRxiv a license to display the preprint in perpetuity. It is made available under aCC-BY-NC-ND 4.0 International license.

Organ-specific and $\mathrm{O}_{2}$-dependent endothelial hypoxia responses

Figure 6: Brain and Lung MVEC have different patterns of mitochondrial ETC components

Whole protein extracts were collected from MVEC from the three baseline $\left(21 \%, 10 \% \mathrm{O}_{2}\right.$ and $\left.5 \% \mathrm{O}_{2}\right)$ and after exposure of each to $1 \% \mathrm{O}_{2}$ for $24 \mathrm{~h}$. The lysates were probed by western blot using a mitochondrial antibody cocktail.

(A) Representative images are shown for lung MVEC from each $\mathrm{O}_{2}$ environment

(B) Quantification of the bMVEC western blots was done following densitometry and normalization loading control and each condition compared to levels at $21 \% \mathrm{O}_{2}$; Data is shown as $\log _{2}$ (fold change) $\pm \mathrm{SD}$ and significance was assessed by one sample t-test; ${ }^{*} p<0.05$,

${ }^{* *} \mathrm{p}<0.01, \mathrm{n}=4$.

(C) Representative images are shown for brain MVEC from each $\mathrm{O}_{2}$ environment

(D) Quantification of the bMVEC western blots was done following densitometry and normalization loading control and each condition compared to levels at $21 \% \mathrm{O}_{2}$; Data is shown as $\log _{2}$ (fold change) $\pm \mathrm{SD}$ and significance assessed by one sample t-test; $* p<0.05$, $*^{*} p<0.01, n=4$. Complex I was detected at levels below threshold for accurate quantification.

(E) SDH activity and (F) succinate levels at baseline and after hypoxia ( $24 \mathrm{~h}$ at $1 \% \mathrm{O}_{2}$ ), following priming in physioxia ( $5 \% \mathrm{O}_{2}$ for brain, $10 \% \mathrm{O}_{2}$ for lung) and hyperoxia $\left(21 \% \mathrm{O}_{2}\right)$. Data is shown as average $\pm \mathrm{SEM}$ and significance was assessed by 2-way ANOVA, HolmSidak's multiple comparison's test, ${ }^{* *} \mathrm{p}<0.01,{ }^{* * *} \mathrm{p}<0.0001, \mathrm{n}=4$ for bMVEC, and IMVEC at $10 \% \mathrm{O}_{2}, \mathrm{n}=2$ for IMVEC $21 \% \mathrm{O}_{2}$

succinate. Basal SDH activity and changes in succinate levels in IMVEC change within a much lower scale, indicating that this is a finely tuned but likely less relevant aspect of mitochondrial function MVEC originally from the lung.

The signal intensity for all other quantifiable complexes was not different between any conditions in bMVEC, with the notable exception of much lower levels of complexes III and I in hypoxic cells that were primed at 21 $\% \mathrm{O}_{2}$. These two complexes are in fact the two mostly associated with ROS generation downstream of mitochondrial activity.

Quantification of mitochondrial potential using MitoTracker Red CMXRos, in which higher signal intensity correlates with mitochondrial health and activity (Supplementary Figure S5), indeed suggested that bMVEC have lower mitochondrial activity at $21 \% \mathrm{O}_{2}$, and qualitative observation indicates that hyperoxic mitochondria in IMVEC are more active than those from bMVEC. This could be a result of oxidative damage, to which bMVEC mitochondria appear considerably more susceptible.

These opposing oxygen-induced changes in ETC composition (Figure 6) and mitochondrial activity (Supplementary Figure S5) between the two MVEC populations are consistent with the measurements of maximal mitochondrial respiration shown above (Figure 5), where in bMVEC higher maximal OCR occurred at lower baseline oxygen levels (Figure 5A, B, right), and was higher than that of IMVEC after adaptation to hypoxia, if cells were maintained in physiological oxygen. Conversely, when IMVEC were maintained in physiological $\mathrm{O}_{2}$, they lost their mitochondrial spare capacity almost entirely (Figure $5 \mathrm{C}, \mathrm{D}$, middle and right panels).

\section{DISCUSSION}

MVEC are key regulators of organ homeostasis, and control perfusion and permeability locally to match organ demand (Augustin and Koh, 2017; Reiterer and Branco, 2019). Perception and response to oscillations in oxygen availability, whether as a result of changes in tissue need or environmental supply, are essential aspects of MVEC function (Bartoszewski et al., 2019). In this study, primary MVEC from two continuous endothelial capillary networks were isolated from brain and lung tissue, and their responses to hypoxia compared. 
bioRxiv preprint doi: https://doi.org/10.1101/2020.08.25.265926; this version posted August 25, 2020. The copyright holder for this preprint (which was not certified by peer review) is the author/funder, who has granted bioRxiv a license to display the preprint in perpetuity. It is made available under aCC-BY-NC-ND 4.0 International license.

Organ-specific and $\mathrm{O}_{2}$-dependent endothelial hypoxia responses

The distinct responses seen here demonstrate that EC are not only intrinsically heterogeneous (Marcu et al., 2018; Nolan et al., 2013; Ribatti et al., 2002), but functionally and metabolically reprogrammable by $\mathrm{O}_{2}$ exposure.

The canonical transcriptional hypoxia response is known to rely on activation of the HIF pathway and the stabilization of either or both of the main isoforms of HIF- $\alpha$. Brain and IMVECs differentially express HIF isoforms, with IMVECs consistently stabilizing higher levels of HIF-1 $\alpha$ both at baseline physioxia (but not hyperoxia) and after hypoxia exposure; while HIF-1 $\alpha$ is usually associated with acute hypoxia response (Koh and Powis, 2012) the preferred isoform stabilized in bMVEC is HIF-2 $\alpha$, induced by hypoxia to a much higher degree than that seen in IMVEC. Regardless of the preferred HIF- $\alpha$ isoform stabilised in each cell type, however, the mRNA levels of HIF transcriptional targets, specifically those encoding typical hypoxia response genes such as PGK, GLUT1, LDH-A and VEGF, were induced to comparable levels in both MVEC populations (Figure 2), and ultimately these results indicate that the distinct vulnerability to hypoxic insult in these two cell populations is largely HIF-independent.

Endothelial function is intrinsically linked to endothelial metabolism (De Bock et al., 2013; Doddaballapur et al., 2015; Rohlenova et al., 2018; Wong et al., 2017). In this study, baseline metabolic preferences and hypoxiadriven metabolic shifts were measured in the two MVEC and compared to investigate if their distinct responses and tolerance resulted from intrinsic heterogeneity or oxygen priming.

As expected, baseline glycolytic activity was higher MVEC expanded in lower $\mathrm{O}_{2}$. Both MVEC grown in physiological atmospheres ( 5 or $10 \% \mathrm{O}_{2}$ ) had increased maximal glycolytic rates (Figure 3 ), which correlated with increased viability during hypoxia (Figure 2). As hyperoxygenation impaired the ability to upregulate glycolysis during a subsequent hypoxic stimulus, even in the absence of mitochondrial respiration (Figure 3), the differences in glycolytic capacity appear to motivate loss of cell viability. The timing and magnitude of the metabolic shift upon exposure to hypoxia is not only highly dependent on $\mathrm{O}_{2}$ priming, but inherent to the origin of the MVEC (Figure 4). In spite of a relatively narrow challenge (from $5 \%$ to $1 \% \mathrm{O}_{2}$ ), bMVEC are strikingly responsive when compared to the same cells expanded in higher $\mathrm{O}_{2}$ conditions, and severely compromised when cells are maintained at $21 \% \mathrm{O}_{2}$ (Figure 5).

Interestingly, baseline glucose uptake is not affected by environmental $\mathrm{O}_{2}$ and is consistently higher in bMVEC than IMVEC, reflecting the role of brain microvasculature in the active shuttling of glucose to neural tissue (Duelli and Kuschinsky, 2001; Huang et al., 2012; Veys et al., 2020); however, the hypoxia-induced increase in glucose uptake in MVEC from the brain is severely delayed if cells are maintained in supra-physiological $\mathrm{O}_{2}$ levels. This had been previously shown in a study on the effect of hyperbaric oxygen on the brain vasculature (such as experienced during diving) (Wilson and Matschinsky, 2019). Combined, these results suggest that hyperoxic priming compromises the ability of bMVEC to perceive the hypoxic challenge, apparently more so than their capacity to respond. 
bioRxiv preprint doi: https://doi.org/10.1101/2020.08.25.265926; this version posted August 25, 2020. The copyright holder for this preprint (which was not certified by peer review) is the author/funder, who has granted bioRxiv a license to display the preprint in perpetuity. It is made available under aCC-BY-NC-ND 4.0 International license.

Organ-specific and $\mathrm{O}_{2}$-dependent endothelial hypoxia responses

While all EC are assumed to be primarily glycolytic, BMVEC are known to have significantly higher mitochondrial density (Oldendorf et al., 1977), and thus presumably have higher mitochondrial activity. Remarkably, bMVEC only show significantly higher relative mitochondrial respiration rates than IMVEC when expanded in their own physiological atmospheres $\left(5 \% \mathrm{O}_{2}\right)$. The dramatic lower maximal respiration of bMVEC relative to IMVEC, when expanded at $21 \% \mathrm{O}_{2}$, show that hyperoxia is much more damaging to bMVEC. These are also the $\mathrm{O}_{2}$ priming conditions at which bMVEC show a severe delay in induction of glycolysis following hypoxia (Figure 5) and subsequent compromised viability (Figures 1,2).

Mitochondria are obvious sensors of $\mathrm{O}_{2}$ availability (Nanadikar et al., 2019; Rabinovitch et al., 2017; Smith and Schumacker, 2019), and even though their cellular function is commonly associated with efficient generation of cellular ATP, in that process they become main generators of reactive oxygen species (ROS)(Dröse, 2013; Larosa and Remacle, 2018; Zhao et al., 2019); these have been shown to mediate mitochondrial damage and associated high rates of cell death in bovine aortic EC exposed to high $\mathrm{O}_{2}$ (Wang et al., 2015). Importantly, mitochondrial function has also been associated with the integrity of the BBB (Bukeirat et al., 2016; Doll et al., 2015).

Mitochondrial ROS are generated primarily at complexes I and III of the mitochondrial electron transport chain (mETC) (Larosa and Remacle, 2018; Zhao et al., 2019). Whereas in IMVEC all mETC protein complexes decrease almost linearly with decreased $\mathrm{O}_{2}$ availability, the only two complexes seen to decrease in hypoxic bMVEC are precisely complexes I and III, but only if the cells are primed in hyperoxia (Figure 6). Conversely, levels of complex II are higher in physiologically maintained bMVEC, and increase following adaptation to hypoxia, again only if cells are never hyperoxygenated. This suggests that complex II activity is essential for the response in bMVEC to hypoxia, possibly in regulating succinate levels, which are detected at levels 10-fold higher than in IMEVC. Both SDH activity and succinate levels are dramatically affected by hyperoxia in bMVEC. Albeit unclear what the consequences of high succinate might be in these cells, it has been associated with epigenetic regulation of gene expression, and a molecular mediator of signal transduction and metabolic reprogramming (Mills et al., 2016; Tretter et al., 2016). Complex II is a unique transporter in the mETC, the only one that is exclusively encoded in the nuclear genome, and that does not contribute to the proton gradient across the inner mitochondrial membrane (Dröse, 2013). Its role in EC has not been studied, and there is some ambiguity in the existing literature regarding the contribution of this complex to ROS formation (Baysal, 2000; Dröse, 2013; Pfleger et al., 2015; Zhao et al., 2019). However, such studies were performed in hyperoxygenated cells, where such changes would not have been observed (Figure 6D), and to the best of our knowledge, this is the first instance where such assessments were performed while maintaining relevant oxygen tensions. The underlying significance of high succinate levels and high activity of mitochondrial complex II in bMVEC is, however, unclear and worth further investigation, but our data indicates that supra-physiological levels of $\mathrm{O}_{2}$ affect the stability of complex II in bMVEC, presumably corrupting reserve respiratory capacity (Figure 5) 
bioRxiv preprint doi: https://doi.org/10.1101/2020.08.25.265926; this version posted August 25, 2020. The copyright holder for this preprint (which was not certified by peer review) is the author/funder, who has granted bioRxiv a license to display the preprint in perpetuity. It is made available under aCC-BY-NC-ND 4.0 International license.

Organ-specific and $\mathrm{O}_{2}$-dependent endothelial hypoxia responses

(Pfleger et al., 2015), and impairing ROS removal. This is supported by the fact that hyperoxygenated bMVEC become unresponsive to hypoxia. If on one hand, having more mitochondria could make cells more sensitive to $\mathrm{O}_{2}$ oscillations (Figure 4, right panel), on the other hand cells with more mitochondria will generate more ROS, in direct correlation with $\mathrm{O}_{2}$ availability. Thus, the subsequent damage to the mitochondria will in turn compromise the ability to perceive $\mathrm{O}_{2}$ oscillations. This too is supported by the fact that bMVECs cultured at $21 \% \mathrm{O}_{2}$ fare far worse than those from lung; not only do bMVEC undergo a more severe hyperoxic challenge relative to their physioxic setpoint, but these cells also have more mitochondria (Oldendorf et al., 1977) and higher baseline mitochondrial activity (Figure 5, Supplementary figure S5). While a similar effect can be seen in IMVEC, it is much less severe. As IMVEC are exposed to wider oscillations of $\mathrm{O}_{2}$ due to their close proximity to air, they should be inherently more tolerant to higher $\mathrm{O}_{2}$ levels and oxidative stress. Most studies regarding the effects of oxygen in microvascular cells, specifically hyperoxia, are restricted to the lung (Ahmad et al., 2004; Ma et al., 2018; Mach et al., 2011; Narula et al., 1998), and occasionally arterial EC (Li et al., 2018; Suzuki et al., 1997; Wang et al., 2015), when microvascular networks from less oxygenated tissues are likely to be much more susceptible.

During hyperbaric oxygen treatments (HOT), used to treat refractory diabetic lower extremity wounds or radiation injuries, $\mathrm{O}_{2}$ partial pressure can be up to 15 times higher than standard air (Chen et al., 2015; Goldman, 2009), resulting in a 13-fold increase in oxygenation in rat brain tissue (Thom, 1989). Visible acute side effects (seizures) affect very few patients (Banham, 2011), but early studies in rodents reported a $50 \%$ decrease in lung endothelium viability following exposure to pure $\mathrm{O}_{2}$ (Kistler et al., 1967). Even though effects on viability are less pronounced in primates, functional aspects have not been investigated (Kapanci et al., 1969). As of the unfolding the severe acute coronavirus syndrome 2 (SARS-CoV-2) in 2019/2020 pandemic, the use of supplemental oxygen has been also used to combat the resulting hypoxemia, but there is no clear consensus about what the target blood oxygen saturation should be; suggestions range from $90 \%$ up to >96\%(Ni et al., 2019; Rasmussen et al., 2018; Shenoy et al., 2020), with most treatment guidelines opting for intermediate values; although the discussion hinges on patient mortality as the main indicator, if no differences in mortality are observed, our data suggests that liberal use of oxygen should be met with caution. Previous data showed that perioperative hyperoxia increases mortality in patients with pre-existing pathologies (Damiani et al., 2014; Helmerhorst et al., 2015; Wijesinghe et al., 2008), and so the benefits of this practice should also be reassessed (Mattishent et al., 2019; Volk et al., 2017).

This study highlights the detrimental effects of hyperoxia, which are far less considered although demonstrably no less harmful, and underscores the importance of research into organ-specific MVEC physiological and metabolic reprogramming and downstream consequences in disease, treatment, and long-term effects following environmental challenges. 
bioRxiv preprint doi: https://doi.org/10.1101/2020.08.25.265926; this version posted August 25, 2020. The copyright holder for this preprint (which was not certified by peer review) is the author/funder, who has granted bioRxiv a license to display the preprint in perpetuity. It is made available under aCC-BY-NC-ND 4.0 International license.

Organ-specific and $\mathrm{O}_{2}$-dependent endothelial hypoxia responses

\section{ACKNOWLEDGEMENTS}

This work was funded by CRUK Cambridge Centre non-clinical training award to CB/MR (ref. C9685/A23214), and a generous start-up package from the School of Medicine, Dentistry and Biomedical Sciences, Queen's University, Belfast. The authors would like to thank the support from colleagues and peers from Medina lab at WWIEM (CEM-QUB) for insight and technical support with metabolic analyses.

\section{AUTHOR CONTRIBUTIONS}

Conceptualization, CBP, RSJ. Methodology, MR, RSJ, CBP. Investigation, MR, AJE, AB, CB; Writing - Original Draft, CBP. Writing - Review \& Editing, CBP, RSJ, MR; Funding Acquisition, CBP; Resources, RSJ and CBP; Supervision, RSJ, CB.

\section{DECLARATION OF INTERESTS}

The authors declare no competing interests. 
bioRxiv preprint doi: https://doi.org/10.1101/2020.08.25.265926; this version posted August 25, 2020. The copyright holder for this preprint (which was not certified by peer review) is the author/funder, who has granted bioRxiv a license to display the preprint in perpetuity. It is made available under aCC-BY-NC-ND 4.0 International license.

Organ-specific and $\mathrm{O}_{2}$-dependent endothelial hypoxia responses

\section{STAR METHODS}

\section{Isolation of brain MVECs}

Brain MVEC were isolated by incorporating and slightly modifying previously described methods (Coisne et al., 2005; Ruck et al., 2014; Watson et al., 2013; Welser-Alves et al., 2014). Brains of 6-8 wk old male C57BL6/J mice (4-6 animals per isolate), were excised and stored in serum-free DMEM on ice before surgical removal of the olfactory bulbs, cerebellum, and mid-brain white matter. The remaining cortical tissue was rolled on sterile filter paper to remove outer vessels and meninges, and tissue was digested in DMEM containing $2 \mathrm{mg} / \mathrm{mL}$ collagenase A (Roche) and $10 \mu \mathrm{g} / \mathrm{mL}$ DNase I (Roche) at $37^{\circ} \mathrm{C}$ for $1 \mathrm{~h}$, with gentle rotation. Digested tissue was pelleted at $290 \times \mathrm{g}$ and resuspended in DMEM containing $20 \% \mathrm{BSA}(\mathrm{w} / \mathrm{v})$, centrifuged for $10 \mathrm{~min}$ at $1000 \times \mathrm{g}$ to separate the vessel pellet from the buoyant myelin fraction. The cell pellet was resuspended in DMEM and filtered through a $70 \mu \mathrm{M}$ nylon mesh, to remove large vessel fragments, and the filtrate was centrifuged at $290 \times \mathrm{g}$. Pellet was resuspended in a digestion mix containing $2 \mathrm{mg} / \mathrm{mL}$ collagenase/dispase (Roche) and 10 $\mu \mathrm{g} / \mathrm{mL}$ DNase I in DMEM and incubated on a shaker at $37^{\circ} \mathrm{C}$ for $30 \mathrm{~min}$. Following centrifugation at $290 \times \mathrm{g}$, microvascular cell pellets were washed once in DMEM, resuspended in MVEC growth medium supplemented with $4 \mu \mathrm{g} / \mathrm{mL}$ puromycin (Sigma) and plated on cell culture plates precoated with collagen I. Puromycin was maintained in the culture medium for the first 4 days to inhibit growth of non-endothelial cells.

\section{Isolation of lung MVEC}

Lung MVEC were isolated as described previously (Branco-Price et al., 2012) with slight modifications. The same mice used for brain tissue were used, and lungs excised into DMEM, kept on ice. Finely minced lung tissue was digested for $90 \mathrm{~min}$ at $37^{\circ} \mathrm{C}$ in HBSS containing collagenase A ( $\left.2 \mathrm{mg} / \mathrm{ml}\right)$, supplemented with $2 \mathrm{mM}$ $\mathrm{CaCl}_{2}, 2 \mathrm{mM} \mathrm{MgSO}_{4}$, and $20 \mathrm{mM} \mathrm{HEPES}$. Digestion suspension was filtered through a $70 \mu \mathrm{M}$ nylon mesh and washed once in HBSS. Cell pellet was resuspended in PBS containing 0.1\% BSA and incubated with anti-rat IgG Dynabeads (Invitrogen) bound to rat anti-mouse CD31 antibody (BD Pharmingen) for 90 min at $4{ }^{\circ} \mathrm{C}$. The beads were washed three times with $0.1 \%$ BSA in PBS, resuspended in MVEC growth medium, and plated on cell culture plates precoated with collagen I.

\section{MVEC culture and hypoxia treatment}

TC plates were coated with collagen ( $3 \mathrm{mg} / \mathrm{mL}$, Sigma, diluted $1: 10$ in $\mathrm{H}_{2} \mathrm{O}$, and incubated for $2 \mathrm{~h}$ at $37^{\circ} \mathrm{C}$ ). Excess solution was removed and wells rinsed twice with PBS immediately prior to plating. MVEC were expanded in a 1:1 mixture of low-glucose DMEM (Gibco) and F12 HAM nutrient mixture (Sigma), buffered with 20 mM HEPES (Gibco), and supplemented with $1 \%$ nonessential amino acids (Sigma), 2 mM sodium pyruvate (Gibco), 20 \% FBS (Gibco), $75 \mu \mathrm{g} / \mathrm{mL}$ endothelial cell growth supplement (Sigma), and $100 \mu \mathrm{g} / \mathrm{mL}$ heparin (Sigma), and in atmospheres containing $5 \% \mathrm{CO}_{2}$ and either ambient ( $21 \%$ ) or physiological $\mathrm{O}_{2}-$ corresponding to in vivo levels in lung (10\%) and brain (5 \%)(Dings et al., 1998; Miller et al., 2010; Wild et al., 2005). All media and solutions were pre-equilibrated with the appropriate oxygen concentration $12 \mathrm{~h}$ prior to 
bioRxiv preprint doi: https://doi.org/10.1101/2020.08.25.265926; this version posted August 25, 2020. The copyright holder for this preprint (which was not certified by peer review) is the author/funder, who has granted bioRxiv a license to display the preprint in perpetuity. It is made available under aCC-BY-NC-ND 4.0 International license.

Organ-specific and $\mathrm{O}_{2}$-dependent endothelial hypoxia responses

media changes, trypsinization or cell treatments. All hypoxia experiments were carried out in an atmosphere containing $5 \% \mathrm{CO}_{2}$ and $1 \% \mathrm{O}_{2}$ at $37{ }^{\circ} \mathrm{C}$, with controlled humidity, using either a Ruskinn Sci-Tive or a Whitley H35 HEPA hypoxystation. Cells received fresh and pre-equilibrated for $24 \mathrm{~h}$ at $1 \% \mathrm{O}_{2}$ before hypoxia treatments (Newby, Marks and Lyall, 2005).

\section{Viability time course using Propidium lodide}

Brain and lung MVEC were grown to $90 \%$ confluence before being transferred to $1 \% \mathrm{O}_{2}$. At each timepoint, cells were washed once in PBS, detached using 0.25\% trypsin, and resuspended in fresh media. All reagents used had been pre-equilibrated to $1 \% \mathrm{O}_{2}$. Cell viability was assessed using an Adam-MC automated cell counter (NanoEnTek) according to manufacturer's instructions. Cells were incubated with either a total cell stain, containing Propidium lodide (PI) and a lysis agent, or with a non-viable cell stain, containing only PI. Viability was measured as a percentage of non-viable cells compared to total cell number.

\section{Real time viability}

Real time viability was assessed using the RealTime-Glo ${ }^{\text {TM }}$ MT Cell Viability Assay (Promega) according to manufacturer's instructions. 3000 cells were plated one day before the start of the assay on collagen-coated white 96-well plates. Immediately before the start of the assay, MT Cell Viability Substrate and NanoLuc enzyme were added to growth medium pre-equilibrated to the appropriate $\mathrm{O}_{2}$. Luminescence was read every 10 min over $48 \mathrm{~h}$, using a FLUOstar Omega plate reader set to $37{ }^{\circ} \mathrm{C}, 5 \% \mathrm{CO}_{2}$, and at the appropriate oxygen level using an Atmospheric Control Unit (BMG Labtech).

\section{qPCR}

Brain and lung MVEC were grown to 90\% confluence, and either transferred into a hypoxia chamber containing $1 \% \mathrm{O}_{2}$, or maintained at the same oxygen concentration. RNA was isolated using the RNeasy isolation kit (Qiagen) according to manufacturer's instructions. cDNA was synthesised from $1 \mu \mathrm{g}$ of RNA using SuperScript III reverse transcriptase (Invitrogen) according to manufacturer's instructions. All transcript levels were measured in triplicates and normalised to $\mathrm{b}$-actin; fold-changes were calculated in relation to the $4 \mathrm{~h}$ baseline reading.

\section{Western blot analysis}

Brain and lung MVEC were grown to 90\% confluence. The cells were then either transferred into a hypoxia chamber containing $1 \% \mathrm{O}_{2}$ or maintained at the same oxygen concentration in which they were cultured since isolation. In both cases, a media change was carried out at $\mathrm{t}=0$ using oxygen-equilibrated growth medium. Cytoplasmic and nuclear protein were collected after the indicated times using NE-PER Nuclear and Cytoplasmic Extraction Reagents (Thermo-Scientific) according to manufacturer's instructions. Total protein was extracted with RIPA buffer containing protease inhibitors (Roche). Protein concentration was measured using a Pierce ${ }^{\mathrm{TM}}$ BCA Protein Assay Kit (Thermo Scientific). Unless specified otherwise, the amount of protein used per lane was $3 \mu \mathrm{g}$ for nuclear protein and $20 \mu \mathrm{g}$ for cytoplasmic and total protein. Samples were resolved 
bioRxiv preprint doi: https://doi.org/10.1101/2020.08.25.265926; this version posted August 25, 2020. The copyright holder for this preprint (which was not certified by peer review) is the author/funder, who has granted bioRxiv a license to display the preprint in perpetuity. It is made available under aCC-BY-NC-ND 4.0 International license.

Organ-specific and $\mathrm{O}_{2}$-dependent endothelial hypoxia responses

in 3-8\% Tris-Acetate gels (Invitrogen) or 4-12\% Bis-Tris gels (Invitrogen), and subsequently transferred to PVDF membranes using semi-dry blotting cassettes (Power Blotter XL, ThermoFisher Scientific or Trans-Blot Turbo, Bio-Rad). The membranes were probed with primary antibodies $\mathrm{o} / \mathrm{n}$ at $4{ }^{\circ} \mathrm{C}$ followed with HRP-conjugated secondary antibodies for $1 \mathrm{~h}$ at room temperature. All antibodies were diluted in PBST containing $2 \%$ milk. Target bands were detected with Pierce ECL western blot substrate (Thermo Scientific), and quantification was performed using ImageJ.

\section{Western blot for mitochondrial electron transfer chain complexes}

$90 \%$ confluent cells were transferred to $1 \% \mathrm{O}_{2}$ or maintained at the same baseline $\mathrm{O}_{2}$ concentration for $24 \mathrm{~h}$. Protein was collected with ice-cold RIPA buffer and quantified using the Pierce ${ }^{\mathrm{TM}}$ BCA Protein Assay Kit (ThermoFisher). $35 \mathrm{\mu g}$ of protein per sample were separated on 4-12\% Bis-Tris gels and transferred to PVDF membranes. As per manufacturer's advice, samples were not heated prior to gel-separation to prevent damage to mitochondrial complex I, unstable above $50{ }^{\circ} \mathrm{C}$. Total OXPHOS Rodent WB Antibody Cocktail (Abcam) was diluted 1:250 in PBST containing $1 \%$ milk. Western blot steps were performed as above. Bands were visualized using Amersham ECL Western Blotting Detection Reagent (GE Healthcare). Rat heart mitochondrial extract was used as a positive control.

\section{Glucose uptake assays}

$3 \times 10^{4}$ MVEC were seeded per well in a 96-well plate $12 \mathrm{~h}$ before the start of the assay, and either transferred into a hypoxia chamber containing $1 \% \mathrm{O}_{2}$ or maintained at the same oxygen concentration. The start of each hypoxia incubation was staggered such that 2-DG treatment could be carried out at the same time for all conditions. The cells were washed once with PBS and incubated with $0.1 \mathrm{mM}$ 2-DG in PBS for $10 \mathrm{~min}$; glucose uptake was measured using the Glucose Uptake-Glo ${ }^{\text {TM }}$ Assay (Promega) according to manufacturer's instructions. All reagents used were pre-equilibrated to the appropriate $\mathrm{O}_{2}$. Samples were incubated with detection reagent for $2 \mathrm{~h}$ and luminescence was measured with a FLUOstar Omega plate reader. A standard curve of 2-deoxy-glucose-6-phosphate was used to calculate glucose uptake rates. Replicate wells plated at the same time were used to determine the cell number at the time of 2-DG treatment.

\section{Glycolytic and mitochondrial stress tests}

Local $\mathrm{pH}$ and $\mathrm{O}_{2}$ changes in media were measured using a XFe96 Analyzer (Agilent). Appropriate cell density was optimised for each measurement and condition, as mitochondrial stress tests required a lower cell number to avoid anoxia in the well after FCCP treatment; 8,000 MVEC were used for mitochondrial stress tests at baseline, and 5,000 at $1 \% \mathrm{O}_{2}$; For glycolytic stress tests, 10,000 cells were used. MVEC were plated on Seahorse microplates precoated with collagen I and left to adhere for $12 \mathrm{~h}$, then assayed immediately (baseline readings) or transferred to $1 \% \mathrm{O}_{2}$ for $24 \mathrm{~h}$ before assay. Immediately prior to transfer to hypoxia, all wells received fresh medium pre-equilibrated to $1 \% \mathrm{O}_{2}$. Before mitochondria stress tests, all wells were washed twice with Seahorse XF base medium supplemented with $7.8 \mathrm{mM}$ glucose, $2.5 \mathrm{mM}$ glutamine, and $3.5 \mathrm{mM}$ 
bioRxiv preprint doi: https://doi.org/10.1101/2020.08.25.265926; this version posted August 25, 2020. The copyright holder for this preprint (which was not certified by peer review) is the author/funder, who has granted bioRxiv a license to display the preprint in perpetuity. It is made available under aCC-BY-NC-ND 4.0 International license.

Organ-specific and $\mathrm{O}_{2}$-dependent endothelial hypoxia responses

pyruvate. For glycolytic stress tests, Seahorse XF base medium was supplemented with $2.5 \mathrm{mM}$ glutamine only. The $\mathrm{pH}$ of the medium was adjusted to 7.4 using $1 \mathrm{M} \mathrm{NaOH}$. The cells were then equilibrated with assay medium for $45 \mathrm{~min}$ at $37{ }^{\circ} \mathrm{C}$ in a $\mathrm{CO}_{2}$-free atmosphere at the appropriate $\mathrm{O}_{2}$ level. After recording baseline measurements, for mitochondrial stress tests, 1 mM Oligomycin, 1 mM FCCP and combined Antimycin A and Rotenone (0.5 mM each) were added successively. For glycolytic stress tests, successive injections of $10 \mathrm{mM}$ Glucose, $1 \mathrm{mM}$ Oligomycin and $50 \mathrm{mM}$ 2-deoxy glucose were sequentially injected. Changes in $\mathrm{pH}$ and oxygen consumption were tracked in real time after each injection(Chang et al., 2018; Li et al., 2017; Rellick et al., 2016). Each measurement was composed of a mix-wait-measure cycle which lasted $5 \min -1 \min -2 \min$ (XF24 in hypoxia and normoxia), $5 \mathrm{~min}-0 \mathrm{~min}-2 \mathrm{~min}$ (XFe96 in hypoxia), or $3 \mathrm{~min}-0 \mathrm{~min}-3 \mathrm{~min}$ (XFe96 in normoxia), as recommended by the manufacturer. Protein concentration in each well was measured using Pierce $^{\mathrm{TM}}$ BCA Protein Assay Kit (ThermoFisher) after assay, and extracellular acidification rates (ECAR) and oxygen consumption rates (OCR) were normalised to $\mu \mathrm{g}$ of total protein. Basal and maximal rates, as well as spare capacity of glycolysis and oxidative phosphorylation were calculated as defined by the manufacturer.

\section{Real time hypoxia response curves}

Real time hypoxia response curves were measured using a Seahorse XF24-3 analyser. 3 × 104 MVEC per well were plated the day before the assay on Seahorse microplates precoated with collagen I. At the start of the assay, MVEC growth medium was replaced with Seahorse XF base medium supplemented with glucose (7.8 $\mathrm{mM})$, pyruvate $(3.5 \mathrm{mM})$, and glutamine $(2.5 \mathrm{mM})$, matching the concentrations found in MVEC growth medium. Seahorse medium was equilibrated to $1 \% \mathrm{O}_{2}$ for $24 \mathrm{~h}$ prior to start of assay, and ECAR was measured every 20 min for $24 \mathrm{~h}$. Each measurement was composed of a mix-wait-measure cycle which lasted 5 min -1 $\min -2 \mathrm{~min}$, followed by a time delay of $12 \mathrm{~min}$. ECAR was normalised to $\mu \mathrm{g}$ of total protein.

\section{Hypoxia chambers for Seahorse analysers}

For experiments at non-atmospheric $\mathrm{O}_{2}$ conditions, the XF24-3 Analyzer was placed within a gas flowcontrolled Perspex hermetic chamber. The atmosphere was $\mathrm{CO}_{2}$-free and $\mathrm{O}_{2}$ levels were set to either $10 \%, 5 \%$, or $1 \%$. During the assay temperature was controlled within the Seahorse analyser; internal air circulation within chamber was maintained by a fan. The XFe96 Analyzer was placed in a Ruskinn hypoxia chamber, set to either $10 \%, 5 \%$, or $1 \% \mathrm{O}_{2}$ and $0.1 \% \mathrm{CO}_{2}$, as the machine could not be set to $0 \% \mathrm{CO}_{2}$. The chamber was humidity and temperature controlled; internal air circulation was maintained by a fan. In both cases, the instruments as well as all media and calibrant were equilibrated to the hypoxic atmosphere for $12 \mathrm{~h}$ prior to the assay. To avoid reoxygenation, cell culture plates were transported from their incubators to the instrument chamber in an air-tight container, and all washes were carried out within the chamber.

\section{Mitochondrial staining}

MVECs were seeded on sterile glass chamber slides precoated with collagen I and grown to confluence. The cells were stained with fresh $\mathrm{O}_{2}$-equilibrated media containing $200 \mathrm{nM}$ MitoTracker Red CMXRos 
bioRxiv preprint doi: https://doi.org/10.1101/2020.08.25.265926; this version posted August 25, 2020. The copyright holder for this preprint (which was not certified by peer review) is the author/funder, who has granted bioRxiv a license to display the preprint in perpetuity. It is made available under aCC-BY-NC-ND 4.0 International license.

Organ-specific and $\mathrm{O}_{2}$-dependent endothelial hypoxia responses

(ThermoFisher) for $30 \mathrm{~min}$, or DMSO as a negative control. The wells were washed twice with PBS and the cells were fixed with cold acetone $\left(-20^{\circ} \mathrm{C}\right)$ for $10 \mathrm{~min}$ and permeabilised with $0.5 \%$ Triton-X100 in PBS for 5 min at room temperature. Blocking was done using 10\% donkey serum in PBS for $1 \mathrm{~h}$ at room temperature. Primary VE-Cadherin antibody was diluted in blocking solution (1:50, R\&D Systems) and the slides were probed over night at $4{ }^{\circ} \mathrm{C}$, followed by secondary antibody (Goat IgG conjugated with AlexaFluor 488 ) at room temperature for $1 \mathrm{~h}$. Secondary-only control wells were kept in blocking solution instead of primary antibody overnight and then received the same dose of secondary antibody. Slides were mounted using ProLong Diamond Antifade with DAPI (ThermoFisher). All images were obtained with a Leica DM5500 B Fluorescence Microscope and analysed using ImageJ.

\section{Migration assays}

Fully confluent MVEC in a 12-well plate were treated for $2 \mathrm{~h}$ with $10 \mathrm{mM}$ Mitomycin $\mathrm{C}$ (or equal volume of vehicle control) in adequately $\mathrm{O}_{2}$-equilibrated, serum-free growth medium. A vertical scratch was applied to the plate using a P1000 tip to create a gap in the cell monolayer. The wells were washed twice with PBS to remove detached cells and incubated with fresh oxygen-equilibrated growth medium. Wells were imaged at $\mathrm{T}=0,2,4,8,24$, and $48 \mathrm{~h}$. The area of the scratch was measured using ImageJ and normalised to the area at $\mathrm{t}$ $=0$ to assess percent closure.

\section{Succinate dehydrogenase assay}

Extracts and assay were performed using a commercial succinate assay kit (Abcam), with minor modifications. Confluent wells of 6-well plates were rinsed in ice-cold PBS and resuspended in $100 \mathrm{~mL}$ of ice-cold SDH Assay Buffer (provided), both of which pre-equilibrated to the adequate $\mathrm{O}_{2}$ levels $\left(21 \%, 10 \%, 5 \%\right.$ or $\left.1 \% \mathrm{O}_{2}\right)$. Cells were scrapped from wells using cell lifters, then transferred to pre-cooled microfuge tubes and homogenized by pipetting. Clear extracts were used for assay, and conversion of substrate (DCIP, provided) was assessed by following changes in absorbance at $600 \mathrm{~nm}$ over time. Measurements in kinetic mode were made continuously for $30 \mathrm{~min}$, and linear range selected to calculate changes of absorbance over time (DOD/ DT). DOD was converted to nmol of DCIP following subtraction of background and against a standard curve. Results were normalized to amount of protein used per well.

\section{Succinate assay}

Extracts and assay were performed using a commercial succinate assay kit (Abcam) with minor modifications. Confluent wells of 6-well plates were rinsed in ice-cold PBS and resuspended in $100 \mathrm{~mL}$ of ice-cold succinate assay buffer (provided), both of which pre-equilibrated to the adequate $\mathrm{O}_{2}$ levels $(21 \%, 10 \%, 5 \%$ or $1 \%$ ). Cells were scrapped from wells using cell lifters, then transferred to pre-cooled microfuge tubes and homogenized by pipeting. Cleared supernatant was deproteinated through a $10 \mathrm{kDa}$ filter column. Filtrates $(10 \mathrm{~mL})$ were used for assay, and background wells (lacking succinate converter) were ran in parallel for each sample. 
bioRxiv preprint doi: https://doi.org/10.1101/2020.08.25.265926; this version posted August 25,2020 . The copyright holder for this preprint (which was not certified by peer review) is the author/funder, who has granted bioRxiv a license to display the preprint in perpetuity. It is made available under aCC-BY-NC-ND 4.0 International license.

Organ-specific and $\mathrm{O}_{2}$-dependent endothelial hypoxia responses Endpoint measurements were performed at $450 \mathrm{~nm}$ and quantification following a 30 min incubation at 37 ${ }^{\circ} \mathrm{C}$. Quantification of succinate was performed against a standard curve, after background correction, and subsequently normalized to amount of protein used in each well (calculated from BCA assay, performed prior to deproteination).

\section{Statistical Analysis}

Data was analysed in Prism Graphpad 8.3, replicate number and statistical test are described for each experiment.

\section{REFERENCES}

Ahmad, S., Ahmad, A., Ghosh, M., Leslie, C.C., and White, C.W. (2004). Extracellular ATP-mediated signaling for survival in hyperoxia-induced oxidative stress. J Biol Chem 279, 16317-16325.

Aird, W.C. (2011). Endothelial Cell Heterogeneity. Cold Spring Harbor Perspectives in Medicine 2, a006429-a006429.

Allegranzi, B., Zayed, B., Bischoff, P., Kubilay, N.Z., de Jonge, S., de Vries, F., Gomes, S.M., Gans, S., Wallert, E.D., Wu, X., et al. (2016). New WHO recommendations on intraoperative and postoperative measures for surgical site infection prevention: an evidence-based global perspective. The Lancet Infectious Diseases 16, e288-e303.

Augustin, H.G., and Koh, G.Y. (2017). Organotypic vasculature: From descriptive heterogeneity to functional pathophysiology. Science 357.

Banham, N.D. (2011). Oxygen toxicity seizures: 20 years' experience from a single hyperbaric unit. Diving Hyperb Med 41 , 202-210.

Bartoszewski, R., Moszyńska, A., Serocki, M., Cabaj, A., Polten, A., Ochocka, R., Dell'Italia, L., Bartoszewska, S., Króliczewski, J., Dąbrowski, M., et al. (2019). Primary endothelial cell-specific regulation of hypoxia-inducible factor (HIF)-1 and HIF-2 and their target gene expression profiles during hypoxia. The FASEB Journal 33, 7929-7941.

Baysal, B.E. (2000). Mutations in SDHD, a Mitochondrial Complex II Gene, in Hereditary Paraganglioma. Science 287, 848851.

Bellot, G.g., Garcia-Medina, R., Gounon, P., Chiche, J., Roux, D.I., Pouysségur, J., and Mazure, N.M. (2009). HypoxiaInduced Autophagy Is Mediated through Hypoxia-Inducible Factor Induction of BNIP3 and BNIP3L via Their BH3 Domains. Molecular and Cellular Biology 29, 2570-2581.

Brahimi-Horn, M.C., Chiche, J., and Pouysségur, J. (2007). Hypoxia and cancer. J Mol Med (Berl) 85, 1301-1307.

Branco-Price, C., Zhang, N., Schnelle, M., Evans, C., Katschinski, Dörthe M., Liao, D., Ellies, L., and Johnson, Randall S. (2012). Endothelial Cell HIF-1 $\alpha$ and HIF-2 $\alpha$ Differentially Regulate Metastatic Success. Cancer Cell 21, 52-65.

Bukeirat, M., Sarkar, S.N., Hu, H., Quintana, D.D., Simpkins, J.W., and Ren, X. (2016). MiR-34a regulates blood-brain barrier permeability and mitochondrial function by targeting cytochrome c. J Cereb Blood Flow Metab 36, 387-392.

Cai, J., and Boulton, M. (2002). The pathogenesis of diabetic retinopathy: old concepts and new questions. Eye (Lond) 16, 242-260.

Cater, D., Garattini, S., Marina, F., and Silver, I. (1961). Changes of oxygen tension in brain and somatic tissues induced by vasodilator and vasoconstrictor drugs. Proceedings of the Royal Society of London Series B Biological Sciences 155, 136157.

Chang, Y., Li, Y., Ye, N., Guo, X., Li, Z., Sun, G., and Sun, Y. (2018). Atorvastatin protects the proliferative ability of human umbilical vein endothelial cells inhibited by angiotensin II by changing mitochondrial energy metabolism. Int J Mol Med 41, 33-42.

Chen, J.-r., Xu, H.-z., Ding, J.-b., and Qin, Z.-y. (2015). Radiotherapy after hyperbaric oxygenation in malignant gliomas. Current Medical Research and Opinion 31, 1977-1984.

Choudry, M., Tang, X., Santorian, T., Wasnik, S., Xiao, J., Xing, W., Lau, K.-H.W., Mohan, S., Baylink, D.J., and Qin, X. (2018). Deficient arginase II expression without alteration in arginase I expression attenuated experimental autoimmune encephalomyelitis in mice. Immunology 155, 85-98.

Coisne, C., Dehouck, L., Faveeuw, C., Delplace, Y., Miller, F., Landry, C., Morissette, C., Fenart, L., Cecchelli, R., Tremblay, P., et al. (2005). Mouse syngenic in vitro blood-brain barrier model: a new tool to examine inflammatory events in cerebral endothelium. Laboratory Investigation 85, 734-746.

Damiani, E., Adrario, E., Girardis, M., Romano, R., Pelaia, P., Singer, M., and Donati, A. (2014). Arterial hyperoxia and mortality in critically ill patients: a systematic review and meta-analysis. Critical Care 18.

De Bock, K., Georgiadou, M., and Carmeliet, P. (2013). Role of Endothelial Cell Metabolism in Vessel Sprouting. Cell Metabolism 18, 634-647. 
bioRxiv preprint doi: https://doi.org/10.1101/2020.08.25.265926; this version posted August 25,2020 . The copyright holder for this preprint (which was not certified by peer review) is the author/funder, who has granted bioRxiv a license to display the preprint in perpetuity. It is made available under aCC-BY-NC-ND 4.0 International license.

Organ-specific and $\mathrm{O}_{2}$-dependent endothelial hypoxia responses

Ding, B.-S., Nolan, D.J., Butler, J.M., James, D., Babazadeh, A.O., Rosenwaks, Z., Mittal, V., Kobayashi, H., Shido, K., Lyden, D., et al. (2010). Inductive angiocrine signals from sinusoidal endothelium are required for liver regeneration. Nature 468 , 310-315.

Ding, B.-S., Nolan, Daniel J., Guo, P., Babazadeh, Alexander O., Cao, Z., Rosenwaks, Z., Crystal, Ronald G., Simons, M., Sato, Thomas N., Worgall, S., et al. (2011). Endothelial-Derived Angiocrine Signals Induce and Sustain Regenerative Lung Alveolarization. Cell 147, 539-553.

Ding, B.S., Gomi, K., Rafii, S., Crystal, R.G., and Walters, M.S. (2015). Endothelial MMP14 is required for endothelialdependent growth support of human airway basal cells. Journal of Cell Science 128, 2983-2988.

Dings, J., Meixensberger, J., Jäger, A., and Roosen, K. (1998). Clinical Experience with 118 Brain Tissue Oxygen Partial Pressure Catheter Probes. Neurosurgery 43, 1082-1094.

Doddaballapur, A., Michalik, K.M., Manavski, Y., Lucas, T., Houtkooper, R.H., You, X., Chen, W., Zeiher, A.M., Potente, M., Dimmeler, S., et al. (2015). Laminar Shear Stress Inhibits Endothelial Cell Metabolism via KLF2-Mediated Repression of PFKFB3. Arteriosclerosis, Thrombosis, and Vascular Biology 35, 137-145.

Doll, D.N., Hu, H., Sun, J., Lewis, S.E., Simpkins, J.W., and Ren, X. (2015). Mitochondrial crisis in cerebrovascular endothelial cells opens the blood-brain barrier. Stroke 46, 1681-1689.

Dröse, S. (2013). Differential effects of complex II on mitochondrial ROS production and their relation to cardioprotective pre- and postconditioning. Biochimica et Biophysica Acta (BBA) - Bioenergetics 1827, 578-587.

Duelli, R., and Kuschinsky, W. (2001). Brain Glucose Transporters: Relationship to Local Energy Demand. Physiology 16, 71-76.

Duellman, S.J., Zhou, W., Meisenheimer, P., Vidugiris, G., Cali, J.J., Gautam, P., Wennerberg, K., and Vidugiriene, J. (2015). Bioluminescent, Nonlytic, Real-Time Cell Viability Assay and Use in Inhibitor Screening. Assay Drug Dev Technol 13, 456465.

Eltzschig, H.K., and Carmeliet, P. (2011). Hypoxia and inflammation. N Engl J Med 364, 656-665.

Gimbrone, M.A., and García-Cardeña, G. (2016). Endothelial Cell Dysfunction and the Pathobiology of Atherosclerosis. Circulation Research 118, 620-636.

Goldman, R.J. (2009). Hyperbaric Oxygen Therapy for Wound Healing and Limb Salvage: A Systematic Review. PM\&R 1, 471-489.

Gupta, K.K., Donahue, D.L., Sandoval-Cooper, M.J., Castellino, F.J., and Ploplis, V.A. (2015). Abrogation of plasminogen activator inhibitor-1-vitronectin interaction ameliorates acute kidney injury in murine endotoxemia. PLoS One 10, e0120728.

Helmerhorst, H.J.F., Roos-Blom, M.-J., van Westerloo, D.J., and de Jonge, E. (2015). Association Between Arterial Hyperoxia and Outcome in Subsets of Critical Illness. Critical Care Medicine 43, 1508-1519.

Hopf, H.W. (1997). Wound Tissue Oxygen Tension Predicts the Risk of Wound Infection in Surgical Patients. Archives of Surgery 132, 997.

Huang, Y., Lei, L., Liu, D., Jovin, I., Russell, R., Johnson, R.S., Di Lorenzo, A., and Giordano, F.J. (2012). Normal glucose uptake in the brain and heart requires an endothelial cell-specific HIF-1 $\alpha$-dependent function. Proceedings of the National Academy of Sciences 109, 17478.

Kapanci, Y., Weibel, E.R., Kaplan, H.P., and Robinson, F.R. (1969). Pathogenesis and reversibility of the pulmonary lesions of oxygen toxicity in monkeys. II. Ultrastructural and morphometric studies. Lab Invest 20, 101-118.

Keith, B., Johnson, R.S., and Simon, M.C. (2011). HIF1 $\alpha$ and HIF2 $\alpha$ : sibling rivalry in hypoxic tumour growth and progression. Nature Reviews Cancer 12, 9-22.

Kent, B.D., Mitchell, P.D., and McNicholas, W.T. (2011). Hypoxemia in patients with COPD: cause, effects, and disease progression. Int J Chron Obstruct Pulmon Dis 6, 199-208.

Kistler, G.S., Caldwell, P.R.B., and Weibel, E.R. (1967). DEVELOPMENT OF FINE STRUCTURAL DAMAGE TO ALVEOLAR AND CAPILLARY LINING CELLS IN OXYGEN-POISONED RAT LUNGS. The Journal of Cell Biology 32, 605-628.

Koh, M.Y., and Powis, G. (2012). Passing the baton: the HIF switch. Trends in Biochemical Sciences 37, 364-372.

Krotova, K., Patel, J.M., Block, E.R., and Zharikov, S. (2010). Hypoxic upregulation of arginase II in human lung endothelial cells. American Journal of Physiology-Cell Physiology 299, C1541-C1548.

Krützfeldt, A., Spahr, R., Mertens, S., Siegmund, B., and Piper, H.M. (1990). Metabolism of exogenous substrates by coronary endothelial cells in culture. J Mol Cell Cardiol 22, 1393-1404.

Larosa, V., and Remacle, C. (2018). Insights into the respiratory chain and oxidative stress. Bioscience reports 38, BSR20171492.

Li, Q., Lin, Y., Wang, S., Zhang, L., and Guo, L. (2017). GLP-1 Inhibits High-Glucose-Induced Oxidative Injury of Vascular Endothelial Cells. Scientific Reports 7, 8008.

Li, Y., Zhang, H., Liang, Y., Wang, W., Xu, T., Zhang, J., Xiao, W., and Wang, T. (2018). Effects of hyperbaric oxygen on vascular endothelial function in patients with slow coronary flow. Cardiol J 25, 106-112.

Liu, K.E., and Frazier, W.A. (2015). Phosphorylation of the BNIP3 C-Terminus Inhibits Mitochondrial Damage and Cell Death without Blocking Autophagy. PLOS ONE 10, e0129667. 
bioRxiv preprint doi: https://doi.org/10.1101/2020.08.25.265926; this version posted August 25,2020 . The copyright holder for this preprint (which was not certified by peer review) is the author/funder, who has granted bioRxiv a license to display the preprint in perpetuity. It is made available under aCC-BY-NC-ND 4.0 International license.

Organ-specific and $\mathrm{O}_{2}$-dependent endothelial hypoxia responses

Ma, C., Beyer, A.M., Durand, M., Clough, A.V., Zhu, D., Norwood Toro, L., Terashvili, M., Ebben, J.D., Hill, R.B., Audi, S.H., et al. (2018). Hyperoxia Causes Mitochondrial Fragmentation in Pulmonary Endothelial Cells by Increasing Expression of Pro-Fission Proteins. Arteriosclerosis, Thrombosis, and Vascular Biology 38, 622-635.

Mach, W.J., Thimmesch, A.R., Pierce, J.T., and Pierce, J.D. (2011). Consequences of hyperoxia and the toxicity of oxygen in the lung. Nurs Res Pract 2011, 260482.

Macias, D., Cowburn, A.S., Torres-Torrelo, H., Ortega-Sáenz, P., López-Barneo, J., and Johnson, R.S. (2018). HIF-2 $\alpha$ is essential for carotid body development and function. Elife 7.

Marcu, R., Choi, Y.J., Xue, J., Fortin, C.L., Wang, Y., Nagao, R.J., Xu, J., MacDonald, J.W., Bammler, T.K., Murry, C.E., et al. (2018). Human Organ-Specific Endothelial Cell Heterogeneity. iScience 4, 20-35.

Mattishent, K., Thavarajah, M., Sinha, A., Peel, A., Egger, M., Solomkin, J., de Jonge, S., Latif, A., Berenholtz, S., Allegranzi, B., et al. (2019). Safety of $80 \%$ vs 30-35\% fraction of inspired oxygen in patients undergoing surgery: a systematic review and meta-analysis. British Journal of Anaesthesia 122, 311-324.

Miller, G.W., Mugler III, J.P., Altes, T.A., Cai, J., Mata, J.F., de Lange, E.E., Tobias, W.A., Cates, G.D., and Brookeman, J.R. (2010). A short-breath-hold technique for lung pO2 mapping with 3He MRI. Magnetic Resonance in Medicine 63, 127136.

Mills, E.L., Kelly, B., Logan, A., Costa, A.S.H., Varma, M., Bryant, C.E., Tourlomousis, P., Däbritz, J.H.M., Gottlieb, E., Latorre, I., et al. (2016). Succinate Dehydrogenase Supports Metabolic Repurposing of Mitochondria to Drive Inflammatory Macrophages. Cell 167, 457-470.e413.

Mistry, N., Mazer, C.D., Sled, J.G., Lazarus, A.H., Cahill, L.S., Solish, M., Zhou, Y.Q., Romanova, N., Hare, A.G.M., Doctor, A., et al. (2018). Red blood cell antibody-induced anemia causes differential degrees of tissue hypoxia in kidney and brain. Am J Physiol Regul Integr Comp Physiol 314, R611-r622.

Nanadikar, M.S., Vergel Leon, A.M., Borowik, S., Hillemann, A., Zieseniss, A., Belousov, V.V., Bogeski, I., Rehling, P., Dudek, J., and Katschinski, D.M. (2019). O(2) affects mitochondrial functionality ex vivo. Redox Biol 22, 101152.

Narula, P., Xu, J., Kazzaz, J.A., Robbins, C.G., Davis, J.M., and Horowitz, S. (1998). Synergistic cytotoxicity from nitric oxide and hyperoxia in cultured lung cells. Am J Physiol 274, L411-416.

Ni, Y.-N., Wang, Y.-M., Liang, B.-M., and Liang, Z.-A. (2019). The effect of hyperoxia on mortality in critically ill patients: a systematic review and meta analysis. BMC Pulmonary Medicine 19, 53.

Nolan, Daniel J., Ginsberg, M., Israely, E., Palikuqi, B., Poulos, M.G., James, D., Ding, B.-S., Schachterle, W., Liu, Y., Rosenwaks, Z., et al. (2013). Molecular Signatures of Tissue-Specific Microvascular Endothelial Cell Heterogeneity in Organ Maintenance and Regeneration. Developmental Cell 26, 204-219.

Oldendorf, W.H., Cornford, M.E., and Brown, W.J. (1977). The large apparent work capability of the blood-brain barrier: A study of the mitochondrial content of capillary endothelial cells in brain and other tissues of the rat. Annals of Neurology 1, 409-417.

Pfleger, J., He, M., and Abdellatif, M. (2015). Mitochondrial complex II is a source of the reserve respiratory capacity that is regulated by metabolic sensors and promotes cell survival. Cell Death \& Disease 6, e1835-e1835.

Prefaut, C., Durand, F., Mucci, P., and Caillaud, C. (2000). Exercise-Induced Arterial Hypoxaemia in Athletes. Sports Medicine 30, 47-61.

Rabinovitch, R.C., Samborska, B., Faubert, B., Ma, E.H., Gravel, S.P., Andrzejewski, S., Raissi, T.C., Pause, A., St-Pierre, J., and Jones, R.G. (2017). AMPK Maintains Cellular Metabolic Homeostasis through Regulation of Mitochondrial Reactive Oxygen Species. Cell Rep 21, 1-9.

Rasmussen, B.S., Perner, A., Wetterslev, J., Meyhoff, C.S., and Schjørring, O.L. (2018). Oxygenation targets in acutely ill patients: still a matter of debate. The Lancet 392, 2436-2437.

Reiterer, M., and Branco, C.M. (2019). Endothelial cells and organ function: applications and implications of understanding unique and reciprocal remodelling. The FEBS Journal 287, 1088-1100.

Reiterer, M., and Branco, C.M. (2020). Endothelial cells and organ function: applications and implications of understanding unique and reciprocal remodelling. FEBS J 287, 1088-1100.

Reiterer, M., Colaco, R., Emrouznejad, P., Jensen, A., Rundqvist, H., Johnson, R.S., and Branco, C. (2019). Acute and chronic hypoxia differentially predispose lungs for metastases. Sci Rep 9, 10246.

Reiterer, M., Colaço, R., Emrouznejad, P., Jensen, A., Rundqvist, H., Johnson, R.S., and Branco, C. (2020). Author Correction: Acute and chronic hypoxia differentially predispose lungs for metastases. Scientific Reports 10.

Rellick, S.L., Hu, H., Simpkins, J.W., and Ren, X. (2016). Evaluation of Bioenergetic Function in Cerebral Vascular Endothelial Cells. J Vis Exp.

Ribatti, D., Nico, B., Vacca, A., Roncali, L., and Dammacco, F. (2002). Endothelial Cell Heterogeneity and Organ Specificity. Journal of Hematotherapy \& Stem Cell Research 11, 81-90.

Rohlenova, K., Veys, K., Miranda-Santos, I., De Bock, K., and Carmeliet, P. (2018). Endothelial Cell Metabolism in Health and Disease. Trends in Cell Biology 28, 224-236. 
bioRxiv preprint doi: https://doi.org/10.1101/2020.08.25.265926; this version posted August 25,2020 . The copyright holder for this preprint (which was not certified by peer review) is the author/funder, who has granted bioRxiv a license to display the preprint in perpetuity. It is made available under aCC-BY-NC-ND 4.0 International license.

Organ-specific and $\mathrm{O}_{2}$-dependent endothelial hypoxia responses

Rojas-Camayo, J., Mejia, C.R., Callacondo, D., Dawson, J.A., Posso, M., Galvan, C.A., Davila-Arango, N., Bravo, E.A., Loescher, V.Y., Padilla-Deza, M.M., et al. (2018). Reference values for oxygen saturation from sea level to the highest human habitation in the Andes in acclimatised persons. Thorax 73, 776-778.

Ruck, T., Bittner, S., Epping, L., Herrmann, A.M., and Meuth, S.G. (2014). Isolation of Primary Murine Brain Microvascular Endothelial Cells. Journal of Visualized Experiments.

Schneider, C.A., Rasband, W.S., and Eliceiri, K.W. (2012). NIH Image to ImageJ: 25 years of image analysis. Nat Methods 9, 671-675.

Shenoy, N., Luchtel, R., and Gulani, P. (2020). Considerations for target oxygen saturation in COVID-19 patients: are we under-shooting? BMC Medicine 18, 260.

Smith, K.A., and Schumacker, P.T. (2019). Sensors and signals: the role of reactive oxygen species in hypoxic pulmonary vasoconstriction. J Physiol 597, 1033-1043.

Smith, R.H., Guilbeau, E.J., and Reneau, D.D. (1977). The oxygen tension field within a discrete volume of cerebral cortex. Microvascular Research 13, 233-240.

Suzuki, Y., Aoki, T., Takeuchi, O., Nishio, K., Suzuki, K., Miyata, A., Oyamada, Y., Takasugi, T., Mori, M., Fujita, H., et al. (1997). Effect of hyperoxia on adhesion molecule expression in human endothelial cells and neutrophils. American Journal of Physiology-Lung Cellular and Molecular Physiology 272, L418-L425.

Takeda, N., O'Dea, E.L., Doedens, A., Kim, J.w., Weidemann, A., Stockmann, C., Asagiri, M., Simon, M.C., Hoffmann, A., and Johnson, R.S. (2010). Differential activation and antagonistic function of HIF- isoforms in macrophages are essential for NO homeostasis. Genes \& Development 24, 491-501.

Theret, M., Gsaier, L., Schaffer, B., Juban, G., Ben Larbi, S., Weiss-Gayet, M., Bultot, L., Collodet, C., Foretz, M., Desplanches, D., et al. (2017). AMPKa1-LDH pathway regulates muscle stem cell self-renewal by controlling metabolic homeostasis. Embo j 36, 1946-1962.

Thom, S.R. (1989). Analytic Reviews : Hyperbaric Oxygen Therapy. Journal of Intensive Care Medicine 4, 58-74.

Thom, S.R., Milovanova, T.N., Yang, M., Bhopale, V.M., Sorokina, E.M., Uzun, G., Malay, D.S., Troiano, M.A., Hardy, K.R., Lambert, D.S., et al. (2011). Vasculogenic stem cell mobilization and wound recruitment in diabetic patients: Increased cell number and intracellular regulatory protein content associated with hyperbaric oxygen therapy. Wound Repair and Regeneration 19, 149-161.

Tretter, L., Patocs, A., and Chinopoulos, C. (2016). Succinate, an intermediate in metabolism, signal transduction, ROS, hypoxia, and tumorigenesis. Biochimica et Biophysica Acta (BBA) - Bioenergetics 1857, 1086-1101.

Uchida, T., Rossignol, F., Matthay, M.A., Mounier, R., Couette, S., Clottes, E., and Clerici, C. (2004). Prolonged Hypoxia Differentially Regulates Hypoxia-inducible Factor (HIF)-1 $\alpha$ and HIF-2 $\alpha$ Expression in Lung Epithelial Cells. Journal of Biological Chemistry 279, 14871-14878.

Veys, K., Fan, Z., Ghobrial, M., Bouché, A., García-Caballero, M., Vriens, K., Conchinha, N.V., Seuwen, A., Schlegel, F., Gorski, T., et al. (2020). Role of the GLUT1 Glucose Transporter in Postnatal CNS Angiogenesis and Blood-Brain Barrier Integrity. Circ Res.

Volk, T., Peters, J., and Sessler, D.I. (2017). The WHO recommendation for $80 \%$ perioperative oxygen is poorly justified. Der Anaesthesist 66, 227-229.

Wang, Q., Guerrero, F., Mazur, A., Lambrechts, K., Buzzacott, P., Belhomme, M., and Theron, M. (2015). Reactive Oxygen Species, Mitochondria, and Endothelial Cell Death during In Vitro Simulated Dives. Medicine \& Science in Sports \& Exercise 47, 1362-1371.

Watson, P.M.D., Paterson, J.C., Thom, G., Ginman, U., Lundquist, S., and Webster, C.I. (2013). Modelling the endothelial blood-CNS barriers: a method for the production of robust in vitromodels of the rat blood-brain barrier and blood-spinal cord barrier. BMC Neuroscience 14.

Welser-Alves, J.V., Boroujerdi, A., and Milner, R. (2014). Isolation and Culture of Primary Mouse Brain Endothelial Cells. In Methods in Molecular Biology (Springer New York), pp. 345-356.

Wenger, R., Kurtcuoglu, V., Scholz, C., Marti, H., and Hoogewijs, D. (2015). Frequently asked questions in hypoxia research. Hypoxia, 35.

Wijesinghe, M., Perrin, K., Ranchord, A., Simmonds, M., Weatherall, M., and Beasley, R. (2008). Routine use of oxygen in the treatment of myocardial infarction: systematic review. Heart 95, 198-202.

Wild, J.M., Fichele, S., Woodhouse, N., Paley, M.N.J., Kasuboski, L., and van Beek, E.J.R. (2005). 3D volume-localizedpO2 measurement in the human lung with3He MRI. Magnetic Resonance in Medicine 53, 1055-1064.

Wilson, D.F., and Matschinsky, F.M. (2019). Hyperbaric oxygen toxicity in brain: A case of hyperoxia induced hypoglycemic brain syndrome. Medical Hypotheses 132, 109375.

Wong, B.W., Marsch, E., Treps, L., Baes, M., and Carmeliet, P. (2017). Endothelial cell metabolism in health and disease: impact of hypoxia. The EMBO Journal 36, 2187-2203.

Yao, Y., Nowak, S., Yochelis, A., Garfinkel, A., and Boström, K.I. (2007). Matrix GLA protein, an inhibitory morphogen in pulmonary vascular development. J Biol Chem 282, 30131-30142. 
bioRxiv preprint doi: https://doi.org/10.1101/2020.08.25.265926; this version posted August 25,2020 . The copyright holder for this preprint (which was not certified by peer review) is the author/funder, who has granted bioRxiv a license to display the preprint in perpetuity. It is made available under aCC-BY-NC-ND 4.0 International license.

Organ-specific and $\mathrm{O}_{2}$-dependent endothelial hypoxia responses

Zhang, J., Muri, J., Fitzgerald, G., Gorski, T., Gianni-Barrera, R., Masschelein, E., D'Hulst, G., Gilardoni, P., Turiel, G., Fan, Z., et al. (2020). Endothelial Lactate Controls Muscle Regeneration from Ischemia by Inducing M2-like Macrophage Polarization. Cell Metab 31, 1136-1153.e1137.

Zhao, R.Z., Jiang, S., Zhang, L., and Yu, Z.B. (2019). Mitochondrial electron transport chain, ROS generation and uncoupling (Review). Int J Mol Med 44, 3-15. 
bioRxiv preprint doi: https://doi.org/10.1101/2020.08.25.265926; this version posted August 25, 2020. The copyright holder for this preprint (which was not certified by peer review) is the author/funder, who has granted bioRxiv a license to display the preprint in perpetuity. It is made available under aCC-BY-NC-ND 4.0 International license.

Organ-specific and $\mathrm{O}_{2}$-dependent endothelial hypoxia responses

Key Resources TABLE

\begin{tabular}{|c|c|c|}
\hline REAGENT or RESOURCE & SOURCE & IDENTIFIER \\
\hline \multicolumn{3}{|l|}{ Antibodies } \\
\hline$\beta$-actin (clone AC-15) & Sigma-Aldrich & Cat\# A1978 \\
\hline CD31 (clone MEC 13.3) & BD Pharmingen & Cat\# 553370 \\
\hline FIH (clone D19B3) & Cell Signaling Technology & Cat\# 4426S \\
\hline GAPDH (clone G-9) & Santa Cruz Biotechnology & Cat\# sc-365062 \\
\hline HIF-1 $\alpha$ & Novus Biologicals & Cat\# NB100-449 \\
\hline $\mathrm{HIF}-2 \alpha$ & R\&D Systems & Cat\# AF2997 \\
\hline PHD1 (clone EPR2746) & Abcam & Cat\# ab113077 \\
\hline PHD2 & Novus Biologicals & Cat\# NB100-2219 \\
\hline PHD3 & Novus Biologicals & Cat\# NB100-303 \\
\hline TATA-BP & Abcam & Cat\# ab63766 \\
\hline VE-Cadherin & R\&D Systems & Cat\# AF1002 \\
\hline Goat IgG - HRP conjugated & Santa Cruz Biotechnology & Cat\# sc-2304 \\
\hline Mouse IgG - HRP conjugated & Santa Cruz Biotechnology & Cat\# sc-2314 \\
\hline Rabbit IgG - HRP conjugated & R\&D Systems & Cat\# HAF008 \\
\hline Goat IgG, conjugated with Alexa Fluor 488 & ThermoFisher Scientific & Cat\# A-11055 \\
\hline \multicolumn{3}{|l|}{ Chemicals, Peptides, and Recombinant Proteins } \\
\hline $0.25 \%$ Trypsin & ThermoFisher Scientific & Cat\# 25200056 \\
\hline 2-deoxy glucose & Sigma & Cat\# D6134 \\
\hline Acetone & Sigma & Cat\# 24201 \\
\hline Adam-MC cell viability stain & NanoEnTek & Cat\# ADR-1000 \\
\hline Amersham ECL Western Blotting Detection Reagent & Sigma & Cat\# GERPN2209 \\
\hline Antimycin A & Sigma & Cat\# A8674 \\
\hline BSA & Sigma & Cat\# A7906 \\
\hline Collagen I & Sigma & Cat\# C4243 \\
\hline Collagenase A & Roche & Cat\# 11088793001 \\
\hline Collagenase/Dispase & Roche & Cat\# 10269638001 \\
\hline cOmplete ${ }^{\mathrm{TM}}$ Protease Inhibitor Cocktail & Roche & Cat\# 11697498001 \\
\hline Dnase I & Roche & Cat\# 11284932001 \\
\hline Donkey Serum & Sigma & Cat\# 566460 \\
\hline Dynabeads coated with sheep anti-rat IgG & ThermoFisher Scientific & Cat\# 11035 \\
\hline Endothelial cell growth supplement & Sigma & Cat\# E2759 \\
\hline F12 HAM nutrient mixture & Sigma & Cat\# 51651C \\
\hline FBS & Gibco & Cat\# 10270106 \\
\hline FCCP & Sigma & Cat\# C2920 \\
\hline Glucose & Sigma & Cat\# G8769 \\
\hline HBSS & ThermoFisher Scientific & Cat\# 14175129 \\
\hline Heparin & Sigma & Cat\# H3149 \\
\hline HEPES & Sigma & Cat\# 15630-056 \\
\hline Low-glucose DMEM & Sigma & Cat\# D6046 \\
\hline Mitomycin C & Sigma & Cat\# D6046 \\
\hline MitoTracker Red CMXRos & ThermoFisher Scientific & Cat\# M7512 \\
\hline $\begin{array}{l}\text { NE-PER }{ }^{\text {TM N}} \text { Nuclear and Cytoplasmic Extraction } \\
\text { Reagents }\end{array}$ & ThermoFisher Scientific & Cat\# 78833 \\
\hline Non-essential amino acids & Sigma & Cat\# M7145 \\
\hline NuPAGE $^{\text {TM }} 3-8 \%$ Tris-Acetate Protein Gels & ThermoFisher Scientific & Cat\# EA0375BOX \\
\hline NuPAGE ${ }^{\mathrm{TM}}$ 4-12\% Bis-Tris Protein Gels & ThermoFisher Scientific & Cat\# NP0321BOX \\
\hline NuPAGE ${ }^{\text {TM }}$ LDS Sample Buffer (4X) & ThermoFisher Scientific & Cat\# NP0007 \\
\hline
\end{tabular}


bioRxiv preprint doi: https://doi.org/10.1101/2020.08.25.265926; this version posted August 25, 2020. The copyright holder for this preprint (which was not certified by peer review) is the author/funder, who has granted bioRxiv a license to display the preprint in perpetuity. It is made available under aCC-BY-NC-ND 4.0 International license.

Organ-specific and $\mathrm{O}_{2}$-dependent endothelial hypoxia responses

\begin{tabular}{|c|c|c|}
\hline REAGENT or RESOURCE & SOURCE & IDENTIFIER \\
\hline$\overline{\text { NuPAGE }{ }^{\text {TM }} \text { Sample Reducing Agent (10X) }}$ & ThermoFisher Scientific & Cat\# NP0004 \\
\hline Oligomycin & Sigma & Cat\# 04876 \\
\hline Pierce ${ }^{\mathrm{TM}}$ ECL Western Blotting Substrate & ThermoFisher Scientific & Cat\# 32209 \\
\hline Power Blotter Select Transfer Stacks, PVDF & ThermoFisher Scientific & Cat\# PB5310 \\
\hline ProLong Diamond Antifade with DAPI & ThermoFisher Scientific & Cat\# P36962 \\
\hline Puromycin Dihydrochloride & Sigma & Cat\# P8833 \\
\hline Rotenone & Sigma & Cat\# R8875 \\
\hline Seahorse XF base medium & Agilent & Cat\# 103334-100 \\
\hline Sodium pyruvate & ThermoFisher Scientific & Cat\# 11360039 \\
\hline Trans-Blot $^{\circledR}$ Turbo $^{\text {TM Mini PVDF Transfer Packs }}$ & Bio-Rad & Cat\# 1704156 \\
\hline Triton-X100 & Sigma & Cat\# T8787 \\
\hline Tween & VWR Chemicals & Cat\# 9005-64-5 \\
\hline \multicolumn{3}{|l|}{ Critical Commercial Assays } \\
\hline RealTime-Glo ${ }^{\text {TM }}$ MT Cell Viability Assay & Promega & Cat\# G9711 \\
\hline RNeasy isolation kit & Qiagen & Cat\# 74106 \\
\hline SuperScript III reverse transcriptase kit & ThermoFisher Scientific & Cat\# 18080093 \\
\hline Pierce ${ }^{\mathrm{TM}}$ BCA Protein Assay Kit & ThermoFisher Scientific & Cat\# 23227 \\
\hline Glucose Uptake-Glo ${ }^{\text {TM }}$ Assay & Promega & Cat\# J1341 \\
\hline Succinate Dehydrogenase Activity Assay Kit & Abcam & Cat\# ab228560 \\
\hline Succinate Assay Kit & Abcam & Cat\# ab204718 \\
\hline \multicolumn{3}{|l|}{ Experimental Models: Cell Lines } \\
\hline Primary Microvascular murine EC & This paper & \\
\hline \multicolumn{3}{|l|}{ Experimental Models: Organisms/Strains } \\
\hline C57/BL6 WT mouse & In house breeding & \\
\hline \multicolumn{3}{|l|}{ Oligonucleotides } \\
\hline Arginase II primer fwd ACCAGGAACTGGCTGAAGTG & \multirow{2}{*}{ (Choudry et al., 2018) } & \\
\hline Arginase II primer rev TGAGCATCAACCCAGATGAC & & \\
\hline$\beta$-actin primer fwd AGAGGGAAATCGTGCGTGAC & \multirow{3}{*}{ (Gupta et al., 2015) } & \\
\hline$\beta$-actin primer rev CAATAGTGATGACCTGGCCGT & & \\
\hline $\begin{array}{l}\beta \text {-actin probe } \\
\text { /FAM/CACTGCCGCATCCTCTTCCTCCC/BHQa-O/ }\end{array}$ & & \\
\hline BNIP3 primer fwd GACGAAGTAGCTCCAAGAGTTCTCA & \multirow{2}{*}{ (Reiterer et al., 2019) } & \\
\hline BNIP3 primer rev CTATTTCAGCTCTGTTGGTATCTTGTG & & \\
\hline Epas1 primer fwd GTCCGAAGGAAGCTGATGG & \multirow{3}{*}{ (Macias et al., 2018) } & \\
\hline Epas1 primer rev TCTATGAGTTGGCTCATGAGTTG & & \\
\hline $\begin{array}{l}\text { Epas1 probe } \\
\text { /FAM/CCACCTGGACAAAGCCTCCATCAT/36-TAMSp/ }\end{array}$ & & \\
\hline GLUT-1 primer fwd GGGCATGTGCTTCCAGTATGT & \multirow{3}{*}{ (Takeda et al., 2010) } & \\
\hline GLUT-1 primer rev ACGAGGAGCACCGTGAAGAT & & \\
\hline $\begin{array}{l}\text { GLUT-1 probe } \\
\text { /FAM/CAACTGTGCGGCCCCTACGTCTTC/BHO/ }\end{array}$ & & \\
\hline HIF-1 $\alpha$ primer fwd GGTGCTGGTGTCCAAAATGTAG & \multirow{3}{*}{ (Macias et al., 2018) } & \\
\hline HIF-1 $\alpha$ primer rev ATGGGTCTAGAGAGATAGCTCCACA & & \\
\hline $\begin{array}{l}\text { HIF-1 } \alpha \text { probe } \\
\text { /FAM/CCTGTTGGTTGCGCAGCAAGCATT/36-TAMSp/ }\end{array}$ & & \\
\hline iNOS primer fwd ACCCTAAGAGTCACCAAAATGGC & \multirow{2}{*}{ (Takeda et al., 2010) } & \\
\hline iNOS primer rev TTGATCCTCACATACTGTGGACG & & \\
\hline LDH-A primer fwd TGTCTCCAGCAAAGACTACTGT & \multirow{2}{*}{ (Theret et al., 2017) } & \\
\hline LDH-A primer rev GACTGTACTTGACAATGTTGGGA & & \\
\hline PGK primer fwd CAAATTTGATGAGAATGCCAAGACT & (Branco-Price et al., 2012) & \\
\hline
\end{tabular}


bioRxiv preprint doi: https://doi.org/10.1101/2020.08.25.265926; this version posted August 25, 2020. The copyright holder for this preprint (which was not certified by peer review) is the author/funder, who has granted bioRxiv a license to display the preprint in perpetuity. It is made available under aCC-BY-NC-ND 4.0 International license.

Organ-specific and $\mathrm{O}_{2}$-dependent endothelial hypoxia responses

\begin{tabular}{|c|c|c|}
\hline REAGENT or RESOURCE & SOURCE & IDENTIFIER \\
\hline PGK primer rev TTCTTGCTGCTCTCAGTACCACA & & \\
\hline $\begin{array}{l}\text { PGK probe } \\
\text { /FAM/TATACCTGCTGGCTGGATGGGCTTGGACT/BHQa } \\
\text {-Q/ }\end{array}$ & & \\
\hline VEGF primer fwd TGAAGCCCTGGAGTGCGT & \multirow{3}{*}{ (Yao et al., 2007) } & \\
\hline VEGF primer rev AGGTTTGATCCGCATGATCTG & & \\
\hline $\begin{array}{l}\text { VEGF probe } \\
\text { /FAM/CCCACGTCAGAGAGCAACATCACCA/BHQa-Q/ }\end{array}$ & & \\
\hline \multicolumn{3}{|l|}{ Software and Algorithms } \\
\hline ImageJ & (Schneider et al., 2012) & $\begin{array}{l}\text { https://imagej.nih.go } \\
\text { v/ij/ }\end{array}$ \\
\hline Mars Version NO. 3.32R & BMG Labtech & $\begin{array}{l}\text { https://www.bmglab } \\
\text { tech.com/mars-data- } \\
\text { analysis-software/ }\end{array}$ \\
\hline Wave 2.6 & Agilent Technologies, Inc. & $\begin{array}{l}\text { https://www.agilent. } \\
\text { com/en/products/ce } \\
\text { Il-analysis/cell- } \\
\text { analysis- } \\
\text { software/data- } \\
\text { analysis/wave- } \\
\text { desktop-2-6 }\end{array}$ \\
\hline Prism 8.3 & GraphPad Software, Inc. & $\begin{array}{l}\text { https://www.graphp } \\
\text { ad.com/scientific- } \\
\text { software/prism/ }\end{array}$ \\
\hline \multicolumn{3}{|l|}{ Other } \\
\hline FLUOstar Omega microplate reader & BMG Labtech & $\begin{array}{l}\text { https://www.bmglab } \\
\text { tech.com/fluostar- } \\
\text { omega/ }\end{array}$ \\
\hline Whitley H35 Hypoxystation & Don Whitley Scientific & $\begin{array}{l}\text { https://www.dwscie } \\
\text { ntific.com/whitley- } \\
\text { hypoxic- } \\
\text { workstations/h35- } \\
\text { hypoxystation }\end{array}$ \\
\hline Seahorse XFe96 Analyzer & Agilent Technologies, Inc. & $\begin{array}{l}\text { https://www.agilent. } \\
\text { com/en/products/ce } \\
\text { II-analysis/seahorse- } \\
\text { analyzers/seahorse- } \\
\text { xfe96-analyzer }\end{array}$ \\
\hline Seahorse XF24-3 Analyzer & Agilent Technologies, Inc. & Discontinued \\
\hline Trans-Blot Turbo Transfer System & Bio-Rad & Cat\# 1704150 \\
\hline Power Blotter XL System & ThermoFisher Scientific & Cat\# PB0013 \\
\hline Leica DM5500 B Fluorescence Microscope & Leica Microsystems & $\begin{array}{l}\text { https://www.leica- } \\
\text { microsystems.com/p } \\
\text { roducts/light- } \\
\text { microscopes/p/leica- } \\
\text { dm5500-b/ }\end{array}$ \\
\hline
\end{tabular}


bioRxiv preprint doi: https://doi.org/10.1101/2020.08.25.265926; this version posted August 25,2020 . The copyright holder for this preprint (which was not certified by peer review) is the author/funder, who has granted bioRxiv a license to display the preprint in perpetuity. It is made available under aCC-BY-NC-ND 4.0 International license.

Organ-specific and $\mathrm{O}_{2}$-dependent endothelial hypoxia responses

\section{RESOURCE AVAILABILITY}

\section{Lead contact}

Further information and requests for resources and reagents should be directed to and will be fulfilled by the Lead Contac, Dr Cristina M Branco (C.Branco@qub.ac.uk)

\section{Materials availability}

This study did not generate new unique materials. 